\title{
Amphidoma languida (Amphidomatacea, Dinophyceae) with a novel azaspiracid toxin profile identified as the cause of molluscan contamination at the Atlantic coast of southern Spain
}

\author{
Urban Tillmann ${ }^{\mathrm{a}, *}$, David Jaén ${ }^{\mathrm{b}}$, Lourdes Fernández ${ }^{\mathrm{b}}$, Marc Gottschling ${ }^{\mathrm{c}}$, Matthias Witt ${ }^{\mathrm{d}}$, \\ Juan Blanco ${ }^{\mathrm{e}}$, Bernd Krock ${ }^{\mathrm{a}}$ \\ a Alfred-Wegener-Institut Helmholtz-Zentrum für Polar- und Meeresforschung, Am Handelshafen 12, D-27570 Bremerhaven, Germany \\ ${ }^{\mathrm{b}}$ Laboratorio de Control de Calidad de los Recursos Pesqueros, Ctra. Punta Umbría-Cartaya, km 12, 21459 Cartaya, Spain \\ ${ }^{c}$ Department Biologie, Systematische Botanik und Mykologie, GeoBio-Center, Ludwig-Maximilians-Universität München, Menzinger Str. 67, D-80638 \\ München, Germany \\ ' Bruker Daltonik GmbH, Fahrenheitstr. 4, 28359 Bremen, Germany \\ e Centro de Investigacións Mariñas, Apdo 13. 36620 Vilanova de Arousa, Spain
}

\section{A R T I C L E I N F O}

\section{Article history:}

Received 21 July 2016

Received in revised form 13 December 2016 Accepted 14 December 2016

Available online $\mathrm{xxx}$

\section{Keywords:}

Amphidoma

Azaspiracids

New compound

AZA-43

Shellfish contamination

Spain

\section{A B S T R A C T}

Azaspiracids (AZA) are a group of food poisoning phycotoxins that are known to accumulate in shellfish. They are produced by some species of the planktonic dinophycean taxon Amphidomataceae. Azaspiracids have been first discovered in Ireland but are now reported in shellfish from numerous global sites thus showing a wide distribution. In shellfish samples collected in 2009 near Huelva (Spain), AZA was also found along the Andalusian Atlantic coast for the first time. Analysis using LC-MS/MS revealed the presence of two different AZA analogues in different bivalve shellfish species (Chamelea gallina, Cerastoderma edule, Donax trunculus, and Solen vagina). In a number of samples, AZA levels exceeded the EU regulatory level of $160 \mu \mathrm{g}$ AZA-1 eq. $\mathrm{kg}^{-1}$ (reaching maximum levels of $>500 \mu \mathrm{g}$ AZA1 eq. $\mathrm{kg}^{-1}$ in Chamelea gallina and $>250 \mu \mathrm{g} \mathrm{AZA-1} \mathrm{eq.} \mathrm{kg}^{-1}$ in Donax trunculus) causing closures of some local shellfish production areas. One dinophyte strain established from the local plankton during the AZA contamination period and determined as Amphidoma languida was in fact toxigenic, and its AZA profile disclosed it as the causative species: it contained AZA-2 as the main compound and the new compound AZA-43 initially detected in the shellfish. AZA-43 had the same mass as AZA-3, but produced different collision induced dissociation (CID) spectra. High resolution mass spectrometric measurements indicated that there is an unsaturation in the $\mathrm{H}$, I ring system of AZA-43 distinguishing it from the classical AZA such as AZA-1, -2, and -3. Furthermore, the Spanish strain was different from the previously reported AZA profile of the species that consist of AZA-38 and AZ-39. In molecular phylogenetics, the Andalusian strain formed a monophyletic group together with other strains of Am. languida, but ITS sequences data revealed surprisingly high intragenomic variability. The first Andalusian case of AZA contamination of shellfish above the EU regulatory limit reported here clearly revealed the risk of azaspiracid poisoning (AZP) for this area and also for the Atlantic coast of Iberia and North Africa. The present study underlines the need for continuous monitoring of AZA and the organisms producing such toxins.

(C) 2016 Elsevier B.V. All rights reserved.

\section{Introduction}

The exploitation of mussels as a food source has a long tradition in Europe, and annual production has considerably increased since

\footnotetext{
* Corresponding author.

E-mail address: urban.tillmann@awi.de (U. Tillmann).
}

1950 (Small, 2002). A main problem for the consumption and trade of bivalve molluscs is the occurrence of toxin-producing algal blooms (HABs) and subsequent closure of harvesting. Among the 5000 species of recent marine phytoplankton, ca 80 species have the capacity to produce potent toxins (Hallegraeff, 2014). These compounds may be accumulated along the food chain, specifically in filter-feeding bivalves and other shellfish, and this has been recognized as a food safety risk ever since the first shellfish-related 


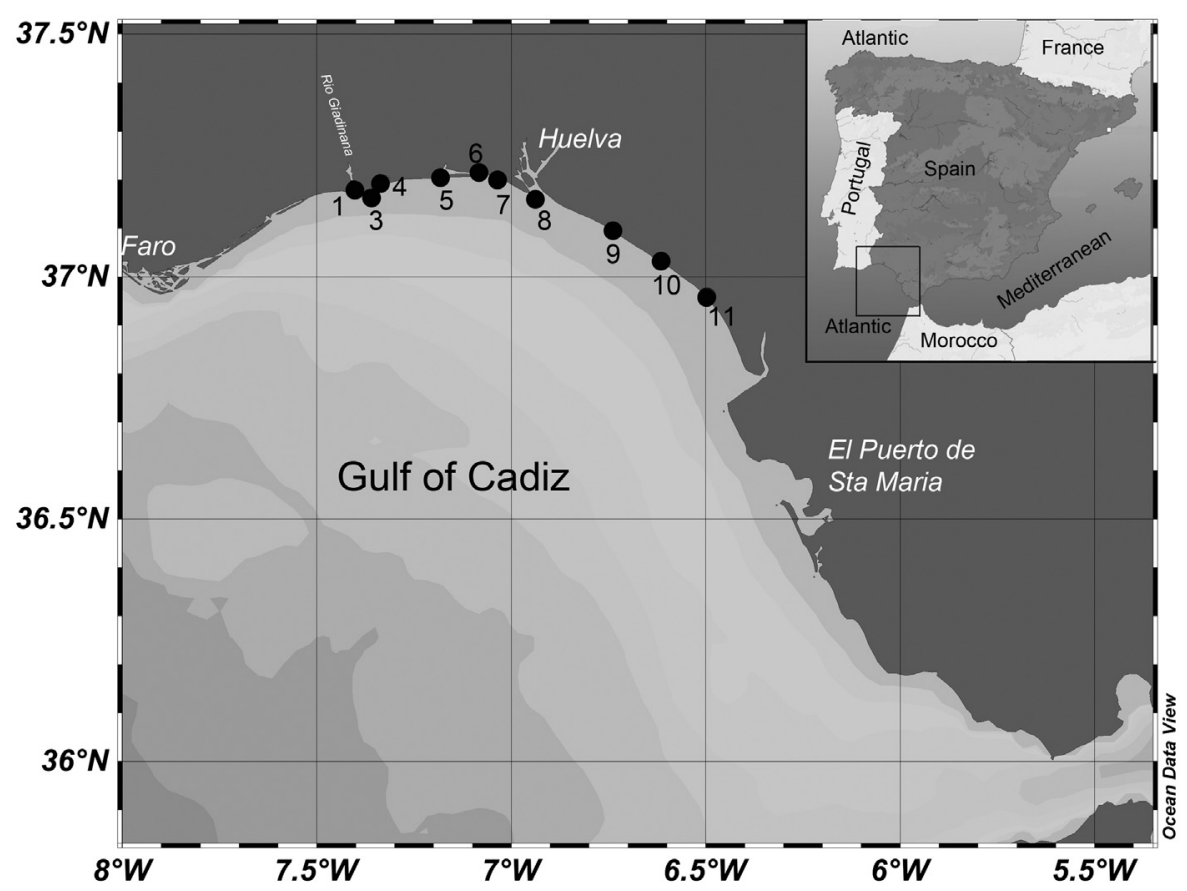

Fig. 1. Study area and location of sampling sites along the Huelva coast, Gulf of Cadiz, Southern Spain.

intoxications of humans have been described. Thus, toxic algal blooms pose serious concerns with regard to public and environmental health as well as to economic activities.

Toxic episodes have detrimental impacts (shellfish harvesters and the aquaculture industry) but also those on human health. Consequently, all countries must quantify those toxins that could pose a human risk, before offering the mollusc products to the market. Based on published food safety regulations for toxins in shellfish, routine monitoring programs are established in Europe today. In the past, they included toxicity tests using the mouse bioassay but have been replaced by chemical quantification of various lipophilic toxins using liquid chromatography-mass spectrometry (LC-MS). Identification and quantification of microalgae present in the water column is performed additionally to provide information about organisms producing toxins.

Among many different groups of microalgal toxins are azaspiracids (AZA), a group of lipophilic compounds discovered almost 20 years ago. They were firstly detected in Mytilus edulis from Ireland following human outbreak of illness in The Netherlands associated with ingestion of contaminated mussels that took place in 1995 (McMahon and Silke, 1996). Since then, a small number of food poisoning incidents have occurred in Europe and the US, all of which were caused by mussels harvested in Ireland (Twiner et al., 2014). Compared to the knowledge on toxin structure, detection methods and toxicology, reliable clarification of the aetiology of azaspiracid shellfish poisoning (AZP) was seriously lacking behind. It took about 14 years from the first human poisoning event until 2009 when a culprit for AZA production was unambiguously identified and described as a novel species, Azadinium spinosum, within a newly created genus (Tillmann et al., 2009). Since then, the known diversity of Azadinium has increased rapidly and now comprises eleven species (Tillmann and Akselman, 2016). Among them, AZA production is found for Azadinium poporum, Azadinium dexteroporum, and Azadinum spinosum (Tillmann et al., 2009; Krock et al., 2012; Percopo et al., 2013). Azaspiracid production, however, is not restricted to Azadinium: With the description of Amphidoma languida, another nanoplanktonic AZA-producing organism of a divergent (but closely related) lineage of the Amphidomataceae was recently identified (Tillmann et al., 2012a).

Azaspiracids seem to be particularly abundant and problematic in Ireland, but they have been reported also in plankton and/or shellfish samples around the world including the US (Trainer et al., 2013), China (Yao et al., 2010), Japan (Ueoka et al., 2009), Chile (Álvarez et al., 2010; López-Rivera et al., 2010), and Argentina (Turner and Goya, 2015). In Europe, AZA have been reported in several adjacent countries of the North Sea such as Norway, Denmark, the UK, and Sweden (James et al., 2002; Torgersen et al., 2008; Krock et al., 2013). Azaspiracids have also been reported from the Atlantic coasts of various other European countries including France (Amzil et al., 2008) and Portugal (Vale et al., 2008) and the Atlantic coast of NW Africa (Taleb et al., 2006). With respect to Spain there is only one report (Braña Magdalena et al., 2003) of AZA identified in bivalves (Mytilus galloprovincialis) from Galicia, which is the main production area of mussels along the European Atlantic coast. Whereas these findings implicate the presence of AZA throughout the entire Atlantic coastline of southern Europe, they had not yet been found in other shellfish production areas of Spain such as Andalusia. Traditionally, natural shellfish beds are harvested along the Andalusian coast line. In addition, mussel Mytilus galloprovincialis farming has gained increasing importance in the area during recent years.

Along the Huelva coast paralytic shellfish poisoning (PSP) toxins (and the producing species Gymnodinium catenatum), as well as domoic acid (and the producing species Pseudo-nitzschia australis), are sporadically recorded (Morales et al., 2001; Mamán et al., 2003). Moreover, there are recurrent spring and summer episodes of species linked to the diarrhetic shellfish poisoning (DSP) syndrome, which are mainly represented by Dinophysis acuta, Dinophysis acuminata and Dinophysis caudata in the area (Jaén et al., 2001; Fernández et al., 2010). Since 2006, estimation of DSP toxicity by mouse bioassay in the shellfish monitoring program of Andalusia is supplemented by analyses of selected samples using LC-MS/MS in order to precisely identify the toxins involved in this 


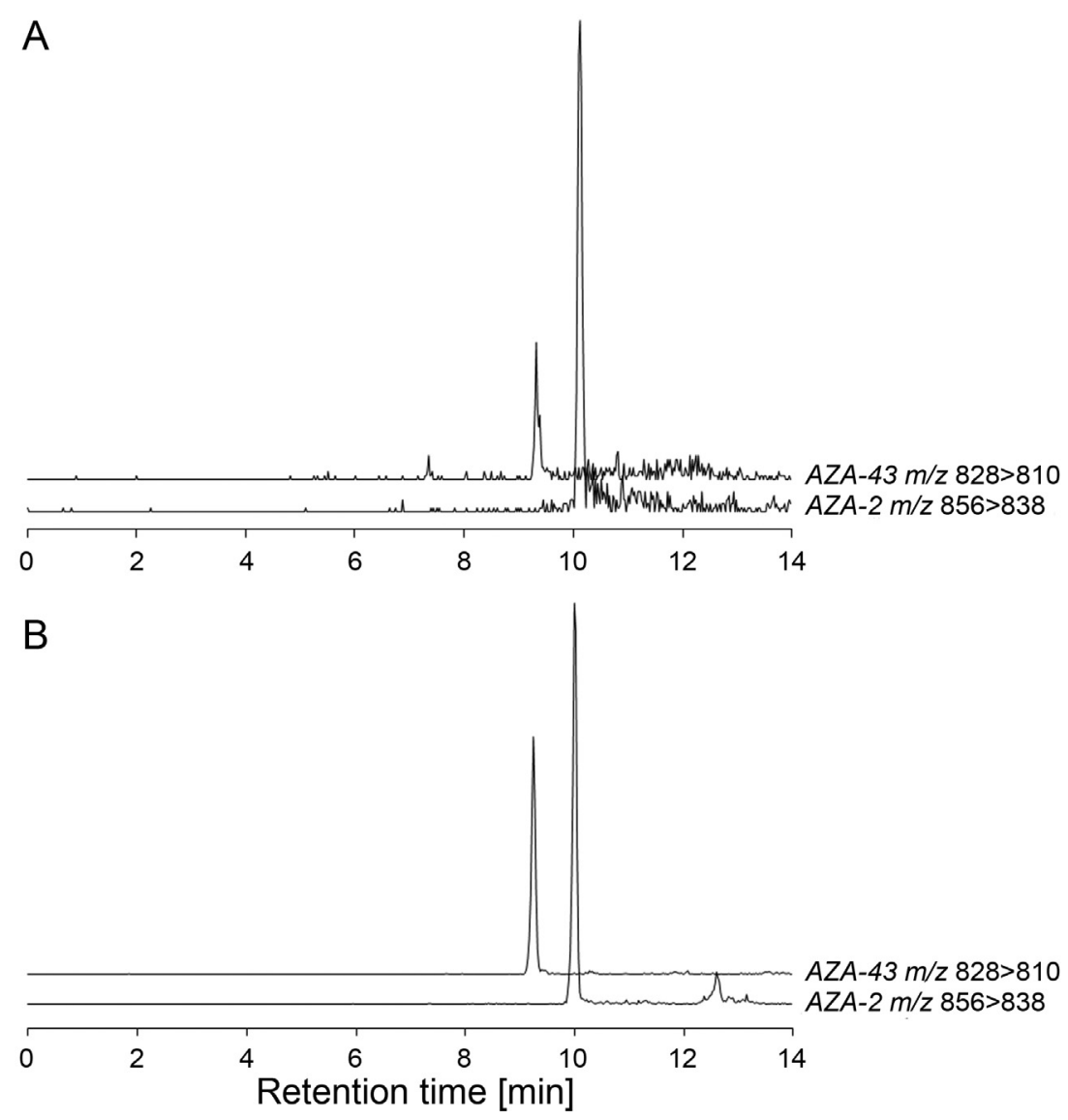

Fig. 2. Ion traces of AZA-2 $(\mathrm{m} / \mathrm{z} 856>838)$ and AZA-43 $(\mathrm{m} / \mathrm{z} 828>810)$ in a bivalve sample (A) and a culture of Amphidoma languida (B).

kind of toxicity. Until 2009, the okadaic acid (OA) group of lipophilic toxins, which includes okadaic acid and dinophysistoxins, was the only group of compounds responsible for DSP toxicity in shellfish in Southwest of Spain (Fernández et al., 2009).

In July 2009, the analysis of shellfish samples using LC-MS/MS revealed the presence of AZA-2 in addition to OA, DTX- 2 and PTX-2, indicating that AZA can also contribute to the DSP toxicity detected by mouse bioassay. For the first time, this report thus confirms the presence of AZA in the Gulf of Cadiz (Spain). The toxins trace their origin back to Am. languida, of which a strain has been established from the local plankton during the AZA contamination period and which is characterized here in terms of morphology, sequence data and AZA profile.

\section{Material \& methods}

\subsection{Sampling}

\subsubsection{Shellfish sampling and extraction}

During a DSP outbreak from July to August in 2009, a total of 86 bivalve samples were collected from different production areas along the Huelva coast (Fig. 1). Extraction was carried out according to EU-Harmonised Standard Operating Procedure (EURLMB-SOP Ver.1, August 2009) for the determination of lipophilic marine biotoxins in molluscs by LC-MS/MS. A portion (ca. $2 \mathrm{~g}$ ) of homogenized tissue was extracted with $9 \mathrm{~mL} 100 \%$ $\mathrm{MeOH}$ in a Vortex mixer at maximum speed for $3 \mathrm{~min}$. The extract was centrifuged at $2000 \times g$ for $10 \mathrm{~min}$, and the supernatant was collected. The pellet was re-suspended in $9 \mathrm{~mL}$ of $\mathrm{MeOH} 100 \%$, homogenized in Ultra-Turrax (IKA) ( $\geq 9500 \mathrm{rpm}$ ) for $1 \mathrm{~min}$, centrifuged and the supernatant was collected and pooled with the first one. The final volume was made up to $20 \mathrm{~mL}$ with $100 \%$ methanol.

\subsubsection{Plankton sampling, algal isolation}

Stimulated by the detection of AZA by mass spectrometry in several shellfish species from the Huelva coast, water samples were collected in the South west coast of Spain (Huelva, Gulf of Cádiz, $37^{\circ} 11^{\prime} \mathrm{N}, 7^{\circ} 02^{\prime} \mathrm{W}$ ) from the areas where AZA had been detected (Fig. 1). Water samples were taken with a combined hose system as described by Lindahl (1986) and screened for the presence of dinophytes similar in morphology and swimming pattern to Amphidomataceae (Tillmann et al., 2009). Corresponding cells were isolated by microcapillary into individual wells of 96-well tissue culture plates (TTP, Trasadingen, Switzerland). Plates were sealed, and isolates were grown non-axenically at $19.5^{\circ} \mathrm{C}$ (14:10 light:dark photocycle) in L1 medium (Guillard and Hargraves, 1993), supplemented with selenite (Dahl et al., 1989). The growth medium was prepared by autoclaving sterile-filtered (Vitipore II $0.22 \mu \mathrm{m}$, Millipore, Bedford, MA, USA) natural seawater (salinity adjusted to 33 with distilled water). Different dinophytes were re-isolated by microcapillary yielding strains free of autotrophic contaminants.

\subsection{Algal culturing and sampling}

Strains were grown in $500 \mathrm{~mL}$ Erlenmeyer flasks at $19.5^{\circ} \mathrm{C}$ under an absolute irradiance of $125 \mu \mathrm{mol}$ quanta $\mathrm{m}^{-2} \mathrm{~s}^{-1}$ to screen 
for the presence of AZA. At exponential phase, $200 \mathrm{~mL}$ of each strain were centrifuged ( 5810 R, Eppendorf, Hamburg, Germany) in $50 \mathrm{~mL}$ centrifuge tubes at $3,220 \times g$ for $10 \mathrm{~min}$. Cell pellets were pooled and centrifuged again (Eppendorf 5702; 2,900 $\times$ g; $10 \mathrm{~min}$ ), and the resulting pellet was stored frozen until extraction.

In one of the strains provisionally named AND-A0920, AZA-2 was detected (see Results), which prompted for a detailed identification of the cultured organism. The strain was subsequently grown in a temperature-controlled growth chamber at $20^{\circ} \mathrm{C}$, a photon flux density of $75 \mu \mathrm{mol}$ quanta $\mathrm{m}^{-2} \mathrm{~s}^{-1}$ and a $16: 8 \mathrm{~h}$ light:dark photocycle. Cells grew in a 1/10 strength K-medium (Keller et al., 1987) prepared from $0.2 \mu \mathrm{m}$ filtered Antarctic seawater (salinity 34, $\mathrm{pH}$ adjusted to 8.0 by adding $1 \mathrm{~N}$ hydrochloric acid). Subcultures were grown for subsequent DNA harvest, AZA toxin analysis and light and electron microscopy. Cell concentrations from exponentially growing cultures were determined by settling Lugol's iodine-fixed samples and counting >600 cells under an inverted microscope. Cells were then harvested by centrifugation (5810R, Eppendorf) in $50 \mathrm{~mL}$ centrifugation tubes at $3,220 \times \mathrm{g}$ for $10 \mathrm{~min}$. For DNA extraction, $50 \mathrm{~mL}$ at a cell density of $33 \times 10^{3} \mathrm{~mL}^{-1}$ were harvested. For a quantitative estimate of AZA cell quotas, six cultures at different cell densities and growth phases were harvested (see Table 4). Cell pellets were transferred to $1 \mathrm{~mL}$ microtubes, centrifuged (Eppendorf $5415,16,000 \times \mathrm{g}$, $5 \mathrm{~min})$, and the resulting pellets were stored frozen $\left(-80^{\circ} \mathrm{C}\right)$ for subsequent DNA extraction and at $-20^{\circ} \mathrm{C}$ for analysis of AZA.

\subsection{Morphological characterization}

Morphological observations and documentation of living and fixed cells of strain AND-A0920 was carried out using various light microscopy systems (all Zeiss, Göttingen, Germany). Specimens were observed with either an inverted Axiovert $200 \mathrm{M}$ or an Axioskop 2 microscope, both equipped with epifluorescence and differential interference contrast optics. For size measurements, cells were harvested from exponentially growing cultures and preserved with $1 \%$ formaldehyde (final concentration). Fixed cells were viewed under an Axioskop 2 microscope and photographed at $1000 \times$ magnification with an Axiovision digital camera. Such micrographs were used to measure length and width of 120 cells with the software program Axiovision (v.4.8, Zeiss).

Examination of thecal plates was performed by scanning electron microscopy (SEM). Cells from an exponentially growing culture were collected by centrifugation (Eppendorf 5810R, $3,220 \times \mathrm{g}$ for $10 \mathrm{~min}$ ) of $15 \mathrm{~mL}$. The supernatant was removed and the cell pellet resuspended in $60 \%$ ethanol in a $2 \mathrm{~mL}$ microtube at $4{ }^{\circ} \mathrm{C}$ for $1 \mathrm{~h}$ to strip off the outer cell membrane. Subsequently, cells were pelleted by centrifugation (Eppendorf $5415 \mathrm{R}$, $16,000 \times \mathrm{g}, 5 \mathrm{~min}$ ) and resuspended in a 60:40 mixture of deionized water and seawater at $4{ }^{\circ} \mathrm{C}$ for $30 \mathrm{~min}$. After centrifugation and removal of the diluted seawater supernatant, cells were fixed with formaldehyde ( $2 \%$ final concentration in a 60:40 mixture of deionized water and seawater) and stored at $4{ }^{\circ} \mathrm{C}$ for $3 \mathrm{~h}$. Cells were then collected on polycarbonate filters (Millipore, $25 \mathrm{~mm} \emptyset$, $3 \mu \mathrm{m}$ pore-size) in a filter funnel, in which all subsequent washing and dehydration steps were carried out. Eight washing steps $(2 \mathrm{~mL}$ Milli-Q-deionised water each) were followed by a dehydration series in ethanol (30, 50, 70, 80, 95, 100\%; 15 min each). Filters were dehydrated with hexamethyldisilazane (HMDS), initially 1:1 HMDS:EtOH followed by $2 \times 100 \%$ HMDS, and stored under gentle vacuum in a desiccator. Finally, filters were mounted on stubs, sputter coated (Emscope SC500, Ashford, UK) with goldpalladium and viewed under FEI Quanta FEG 200 SEM (Eindhoven, The Netherlands). Micrographs were adjusted and presented on a black background using Adobe Photoshop 6.0 (Adobe Systems, San Jose, CA, USA)

\subsection{DNA extraction and phylogenetic analyses}

Genomic DNA from cell pellets of Am. languida strain ANDA0920 was extracted with a NucleoSpin ${ }^{\mathbb{R}}$ Plant II Kit (Macherey Nagel, Düren, Germany) according to the manufacturer's instructions. Various ribosomal RNA loci (18S or small subunit: SSU; Internal Transcribed Spacer region including ITS1, 5.8S rRNA, ITS2; D1/D2 region of $28 \mathrm{~S}$ or large subunit: LSU) were amplified from total DNA by polymerase chain reaction (PCR). The PCR conditions were as follows: HotMasterTaq ${ }^{\circledR}$ (5Prime, Hamburg, Germany) buffer $1 \times, 0.1 \mathrm{mM}$ of dNTPs, $0.1 \mathrm{mM}$ of each forward and reverse primer and 1.25 units of Taq polymerase were added to $10-30 \mathrm{ng}$ of the extracted genomic DNA in total reaction volumes of $50 \mu \mathrm{L}$. For SSU and LSU rRNA amplifications, the following settings were used: initialisation at $95^{\circ} \mathrm{C}$ for $7 \mathrm{~min}$; 35 cycles of $94{ }^{\circ} \mathrm{C}$ for $45 \mathrm{~s}$, $54^{\circ} \mathrm{C}$ for $2 \mathrm{~min}, 70^{\circ} \mathrm{C}$ for $1.5 \mathrm{~min}$; and a final extension at $70^{\circ} \mathrm{C}$ for $5 \mathrm{~min}$. The ITS amplification conditions were: initialisation at $94^{\circ} \mathrm{C}$ for $4 \mathrm{~min}$; 35 cycles at $94^{\circ} \mathrm{C}$ for $45 \mathrm{~s}, 54^{\circ} \mathrm{C}$ for $45 \mathrm{~s}, 70^{\circ} \mathrm{C}$ for $1 \mathrm{~min}$; final extension at $70^{\circ} \mathrm{C}$ for $5 \mathrm{~min}$. Forward and reverse primers for SSU amplification were: $1 \mathrm{~F}\left(5^{\prime}\right.$ - AAC CTG GTT GAT CCT GCC AGT $\left.3^{\prime}\right)$ and $1528 \mathrm{R}\left(5^{\prime}-\right.$ TGA TCC TTC TGC AGG TTC ACC TAC $\left.-3^{\prime}\right)$, for LSU amplification: D1R-F ( $5^{\prime}$ - ACC CGC TGA ATT TAA GCA TA - $\left.3^{\prime}\right)$ and D2C-R (5' - CCT TGG TCC GTG TTT CAA GA - 3') and for ITS amplification: ITS a $\left(5^{\prime}\right.$ - CCA AGC TTC TAG ATC GTA ACA AGG (ACT) TC CGT AGG T $\left.-3^{\prime}\right)$ and ITS b $\left(5^{\prime}-\right.$ CCT GCA GTC GAC A(GT)A TGC TTA A(AG)T TCA GC(AG) GG $-3^{\prime}$ ), respectively, and HotMasterTaq ${ }^{\mathbb{}}$ (5Prime) polymerase was used for PCR experiments.

ITS PCR products were purified, cloned into a TOPO ${ }^{\mathbb{R}}$ TA sequencing vector (Invitrogen, Life Technologies; Darmstadt, Germany) and transformed into One Shot ${ }^{\circledR}$ TOP10 chemically competent $E$. coli (Invitrogen). Purified plasmids of several positive bacterial colonies were sequenced using M13 primers on an ABI $3130 \times \mathrm{L}$ Genetic Analyzer (Applied Biosystems; Darmstadt, Germany).

Forward and reverse sequences were assembled in CLC Main Workbench (CLC Bio, Aarhus, Denmark). Sequences were compared in Se-Al v2.0a72 (Rambaut, 2001), and similarity matrices were calculated using BioEdit v7.0.0 (Hall, 1999). The new sequences were embedded in an existing alignment covering the molecular and morphological diversity known from Amphidomataceae, and phylogenetic analyses were run in the same way as described previously (Tillmann et al., 2014a).

\subsection{Chemical analysis of toxins}

\subsubsection{Shellfish samples}

All solvents and chemicals were high performance liquid chromatography (HPLC) or analytical grade. Acetonitrile, methanol, hydrochloric acid, sodium hydroxide and ammonium hydroxide $(25 \%)$ were purchased from Scharlab (Spain). Ultrapure water was produced by a Milli-Q water purification system (Millipore). Certified reference solutions and mussel tissue reference material were provided by NRC Certified Reference Materials Program (Halifax, Canada).

Shellfish extracts were filtered through a $0.22 \mu \mathrm{m}$ syringe filter before injection into the LC-MS system, an Agilent 1100 series liquid chromatograph (Agilent, Palo Alto, CA, USA) coupled to triple quadrupole mass spectrometer (QTrap, Applied Biosystems, Warrintong, UK) and equipped with an atmospheric pressure electrospray ionization (ESI) interface (Sciex, Toronto, Canada). Separations of lipophilic toxins were performed by reverse-phase chromatography column XBridge C18 $5 \mu \mathrm{m}$ particle size, $3 \mathrm{~mm}$ diameter and $150 \mathrm{~mm}$ length (Waters, Dublin, Ireland), maintained at $40^{\circ} \mathrm{C}$, with gradient elution using an alkaline $(\mathrm{pH} 11)$ mobile phase according to Gerssen et al. (2009). Mobile phase A consisted of $6.7 \mathrm{mM}$ of ammonia in ultrapure water. Mobile phase $B$ 
consisted of $6.7 \mathrm{mM}$ of ammonia in 90:10 (v:v) acetonitrile:water. A gradient was run at a flow rate of $400 \mu \mathrm{L} \mathrm{min}^{-1}$ linearly from $10 \%$ to $90 \%$ B over $5 \mathrm{~min}$, held at $90 \%$ for $3 \mathrm{~min}$ and then decreased to $10 \% \mathrm{~B}$ for equilibration until the next run. For negative ionization mode, a gradient was run at flow rate of $400 \mu \mathrm{L} \mathrm{min}^{-1}$ linearly from $10 \%$ to $90 \%$ B over $9 \mathrm{~min}$, held at $90 \%$ for $1 \mathrm{~min}$ and then decreased to $10 \% \mathrm{~B}$ for equilibration until the next run. The vial compartment of the autosampler was kept at $10^{\circ} \mathrm{C}$ and a $20 \mu \mathrm{L}$ injection volume was used.

Detection was carried out in the negative selected reaction monitoring (SRM) mode for the determination of okadaic acid (OA), dinophysistoxins-(DTX) and yessotoxins (YTX) and in the positive mode for pectenotoxins (PTX), AZA, 13-desmehtyl spirolide C (SPX-1) and gymnodimine A (GYM). Source parameters and transitions in positive mode are compiled in Table S01 in the Supplementary material. Toxin concentrations were estimated by comparing the observed response of the samples with that of reference solutions. In case of compounds for which no reference solution was available at the time of analysis, the structurally closest toxin was used. That was case for AZA-2, -3, PTX-1 and DTX2 , that were quantified using the reference solutions of AZA-1, PTX2 and $\mathrm{OA}$. Toxicities were calculated for each toxin by multiplying the estimated toxin concentration by its corresponding toxicity equivalence factor (TEF) suggested by the European Food Safety Agency (EFSA, 2009).

Retroactively, AZA-43 levels in a few selected mollusc samples were estimated via calibration with an AZA-1 standard and expressed as AZA-1 mass equivalents.

\subsubsection{Screening of raw algal cultures for AZA}

Algal pellets were suspended in $200 \mu \mathrm{L}$ methanol, and sonicated (S250D, Branson, USA; 6 cycles, 60 s, amplitude 20\%). The obtained extract was clarified by centrifugation at $3,220 \mathrm{xg}$ for $10 \mathrm{~min}$ and the supernatant was syringe-filtered through $0.2 \mu \mathrm{m}$ cellulose filters Minisart RC15 (Sartorius). Algal extracts were filtered through a $0.22 \mu \mathrm{m}$ syringe filter into an LC autosampler vial before injection into the LC-MS system. LC and source

Table 1

Azaspiracid toxicity levels ( $\mu \mathrm{g}$ AZA-1 eq kg ${ }^{-1}$ ) in four different shellfish species collected in July/August 2009 at 10 sampling sites (A01-A11) along the Huelva coast. For the location of sampling sites see Figure 1. In most cases one sample per week was taken but in a few cases two samples were taken in one week for Donax trunculus, and both are shown in different lines. Upper table: Donax trunculus; middle table: Chamelea galina; lower table: Cerastoderma edule (regular, upper line) and Solen vagina (bold, lower line). Light shades: values $>80 \mu \mathrm{g}$ AZA- 1 eq. $\mathrm{kg}^{-1}$ (half EU regulatory level). Dark shaded: values $>$ $160 \mu \mathrm{g}$ AZA-1 eq. $\mathrm{kg}^{-1}$ (EU regulatory level).

\begin{tabular}{|c|c|c|c|c|c|c|c|}
\hline \multicolumn{8}{|c|}{ Donax trunculus } \\
\hline Week 2009 & A 04 & A 05 & A 07 & A 08 & A 09 & A 10 & A 11 \\
\hline 06.7.-12.7. & 15.0 & & 19.8 & & & 120.3 & 72.6 \\
\hline 13.7.-19.7. & 25.0 & & 44.1 & 105.0 & 126.6 & & \\
\hline 20.7.-26.7. & 21.0 & 34.8 & 100.4 & 123.4 & 108.1 & 284.5 & 109.1 \\
\hline 27.7.-02.8. & 91.7 & 92.7 & & & & & \\
\hline 03.8.-09.8. & 96.9 & 84.0 & 94.5 & 95.6 & 98.4 & 101.3 & \\
\hline 10.8.-16.8. & 87.7 & 71.0 & 85.2 & 96.6 & & & 81.0 \\
\hline 17.8.23.8. & & 0.0 & 73.3 & 75.6 & $\begin{array}{l}0.0 \\
0.0\end{array}$ & $\begin{array}{l}84.2 \\
0.0 \\
\end{array}$ & \begin{tabular}{|l|}
77.3 \\
0.0 \\
\end{tabular} \\
\hline 24.8.-30.8 & & & 79.0 & 0.0 & & & \\
\hline \multicolumn{8}{|c|}{ Chamelea gallina } \\
\hline Week 2009 & A 04 & A 05 & A 07 & A 08 & A 09 & A 10 & A 11 \\
\hline \multicolumn{8}{|l|}{ 06.7.-12.7. } \\
\hline 13.7.-19.7. & & & & 176.2 & & 0.0 & 150.5 \\
\hline 20.7.-26.7. & 29.8 & 45.2 & & 168.0 & 180.4 & 93.5 & 575.4 \\
\hline 27.7.-02.8. & & 109.5 & & 101.0 & 92,5 & 97.6 & 100.9 \\
\hline 03.8.-09.8. & 86.9 & 94.0 & & 97.2 & 88,0 & & 118.5 \\
\hline $10.8 .-16.8$ & 107.0 & & & 94.0 & 77.7 & 90.0 & \\
\hline 17.8 .23 .8 & & & & 83.0 & & 85,8 & \\
\hline $24.8 .-30.8$ & & & & & & & \\
\hline
\end{tabular}

Cerastoderma edule / Solen vagina

\begin{tabular}{|l|l|l|l|}
\hline Week 2009 & A 01 & A 03 & A 06 \\
\hline 06.7.-12.7. & & & \\
\hline 13.7.-19.7. & & & \\
\hline 20.7.-26.7. & & & 73.5 \\
\hline 27.7.-02.8. & 90.3 & $\mathbf{9 6 . 2}$ & 89.9 \\
\hline 03.8.-09.8. & & & $\mathbf{8 6 . 1}$ \\
\hline 10.8.-16.8. & & & $\mathbf{1 3 9 . 1}$ \\
\hline 17.8.23.8. & & & 81.8 \\
\hline 24.8.-30.8 & & & \\
\hline
\end{tabular}



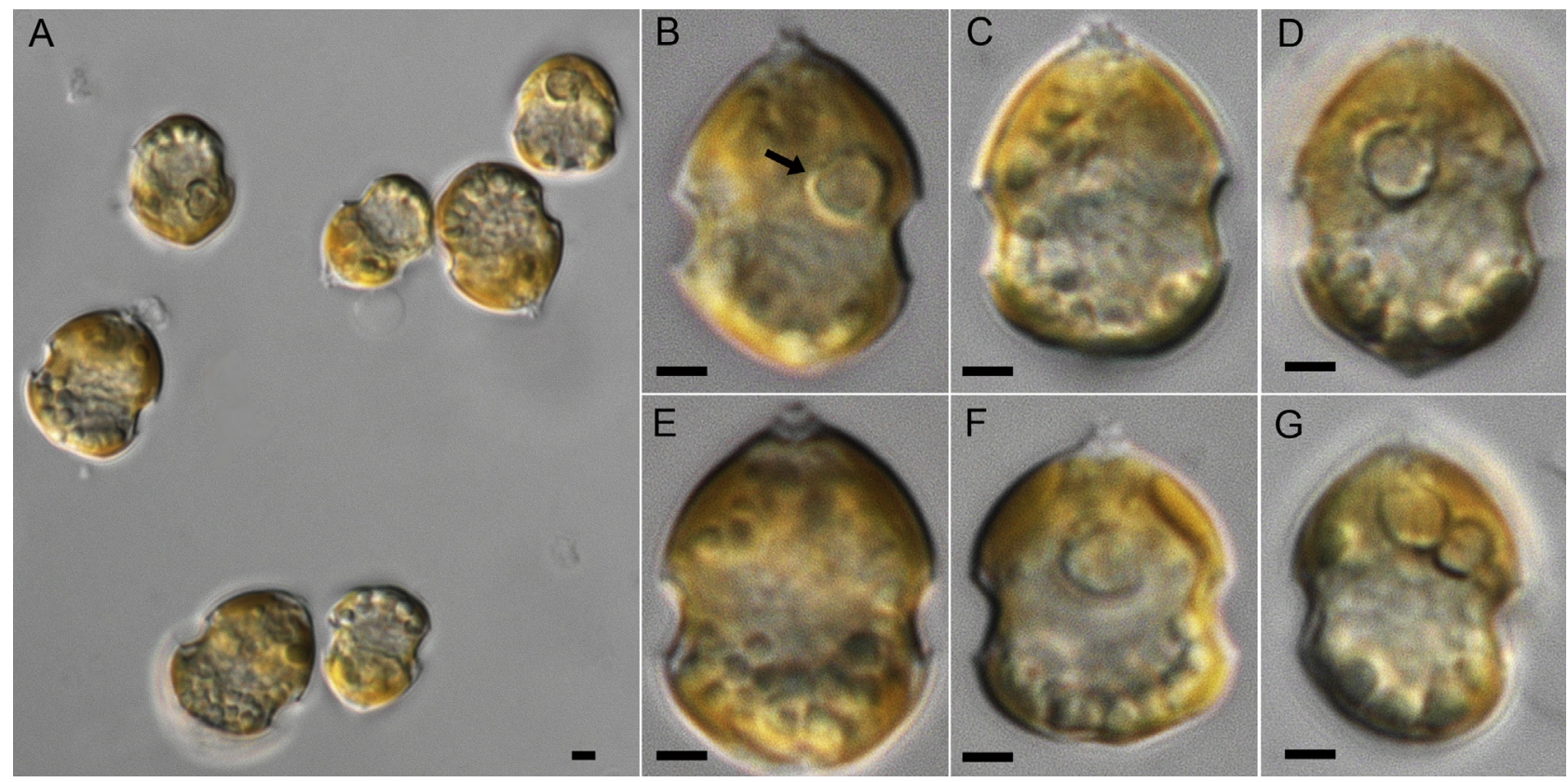

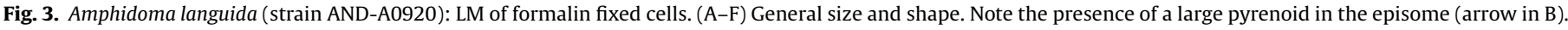
$(G)$ Variations in pyrenoid. A cell with two pyrenoids in the episome. Scale bars $=2 \mu \mathrm{m}$.

parameters and the transitions used for the detection of AZA are listed in Table S01 in the Supplementary material.

\subsubsection{Detailed analysis of Amphidoma languida AND-A0920}

2.5.3.1. Cell extraction. Cell pellets were extracted with $500 \mu \mathrm{L}$ acetone by ultrasonication (Sonotrode, Bandelin HP2070, Berlin, Germany; 70 s; 70 cycles;10\% power). After homogenization, extracts were centrifuged (Eppendorf $5415 \mathrm{R}$ ) at $16,100 \mathrm{xg}$ at $4^{\circ} \mathrm{C}$ for $10 \mathrm{~min}$. Each supernatant was transferred to a $0.45 \mu \mathrm{m}$ pore-size spin-filter (Ultrafree, Millipore, Eschborn, Germany) and centrifuged at $800 \times g$ for $30 \mathrm{~s}$, The resulting filtrate was transferred into a LC autosampler for LC-MS/MS analysis.

2.5.3.2. Single reaction monitoring (SRM) measurements. Water was deionized and purified (Milli-Q Millipore) to $18 \mathrm{M} \Omega \mathrm{cm}^{-1}$ or better quality. Formic acid (90\%, p.a.), acetic acid(p.a.) and ammonium formate (p.a.) were purchased from Merck (Darmstadt, Germany). The solvents, methanol and acetonitrile, were high performance liquid chromatography (HPLC) grade (Merck).

Mass spectral experiments were performed to survey for a wide array of AZA. The analytical system consisted of an API $4000 \mathrm{Q}$ Trap (AB-SCIEX, Darmstadt, Germany), triple quadrupole mass spectrometer equipped with a TurboSpray ${ }^{\mathbb{R}}$ interface coupled to a model 1100 LC (Agilent, Waldbronn, Germany). The LC equipment included a solvent reservoir, in-line degasser (G1379A), binary pump (G1311A), refrigerated autosampler (G1329A/G1330B), and temperature-controlled column oven (G1316A).

Separation of AZA ( $5 \mu \mathrm{L}$ sample injection volume) was performed by reverse-phase chromatography on a $\mathrm{C} 8$ phase. The analytical column $(50 \times 2 \mathrm{~mm})$ was packed with $3 \mu \mathrm{m}$ Hypersil BDS $120 \AA$ (Phenomenex, Aschaffenburg, Germany) and maintained at $20^{\circ} \mathrm{C}$. The flow rate was $0.2 \mathrm{~mL} \mathrm{~min}^{-1}$, and gradient elution was performed with two eluents, where eluent $A$ was water and B was acetonitrile:water $(95: 5 \mathrm{v}: \mathrm{v})$, both containing $2.0 \mathrm{mM}$ ammonium formate and $50 \mathrm{mM}$ formic acid. Initial conditions were 8 min column equilibration with $30 \%$ B, followed by a linear gradient to $100 \% \mathrm{~B}$ in $8 \mathrm{~min}$ and isocratic elution until $18 \mathrm{~min}$ with $100 \% \mathrm{~B}$, then returning to initial conditions until $21 \mathrm{~min}$ (total run time: $29 \mathrm{~min}$ ).

AZA profiles were determined in one period (0-18) min. Selected reaction monitoring (SRM) experiments were carried out in positive ion mode by selecting the transitions compiled together with source parameters in Table S02 in the Supplementary material. AZA-43 was calibrated against an external standard solution of AZA-2 (certified reference material program of the IMBNRC, Halifax, Canada) and its concentration expressed as AZA2 equivalents.

2.5.3.3. Precursor ion experiments. Precursors of the fragments $m / z$ $348, \mathrm{~m} / z 360$ and $\mathrm{m} / \mathrm{z} 362$ were scanned in positive ion mode from $\mathrm{m} / \mathrm{z} 400$ to 950 under the following conditions: curtain gas: $10 \mathrm{psi}$, CAD: medium, ion spray voltage: $5500 \mathrm{~V}$, temperature: ambient, nebulizer gas: 10 psi, auxiliary gas: off, interface heater: on, declustering potential: $100 \mathrm{~V}$, entrance potential: $10 \mathrm{~V}$, collision energy: $70 \mathrm{~V}$, exit potential: $12 \mathrm{~V}$.

2.5.3.4. Product ion spectra. Product ion (collision induced dissociation; CID) spectra of $\mathrm{m} / \mathrm{z} 828$ and $\mathrm{m} / \mathrm{z} 856$ were recorded in the Enhanced Product Ion (EPI) mode in the mass range from $\mathrm{m} / \mathrm{z} 150$ to 930 . Positive ionization and unit resolution mode were used. The following parameters were applied: curtain gas: 10 psi, CAD: medium, ion spray voltage: $5500 \mathrm{~V}$, temperature: ambient, nebulizer gas: 10 psi, auxiliary gas: off, interface heater: on, declustering potential: $100 \mathrm{~V}$, collision energy spread: $0,10 \mathrm{~V}$, collision energy: $70 \mathrm{~V}$.

2.5.3.5. High resolution mass spectrometry. High resolution mass spectra were acquired with a Solarix XR Fourier transform ion cyclotron resonance mass spectrometer (FT-ICR-MS; Bruker Daltonik $\mathrm{GmbH}$, Bremen, Germany) equipped with a $12 \mathrm{~T}$ refrigerated actively shielded superconducting magnet (Bruker 

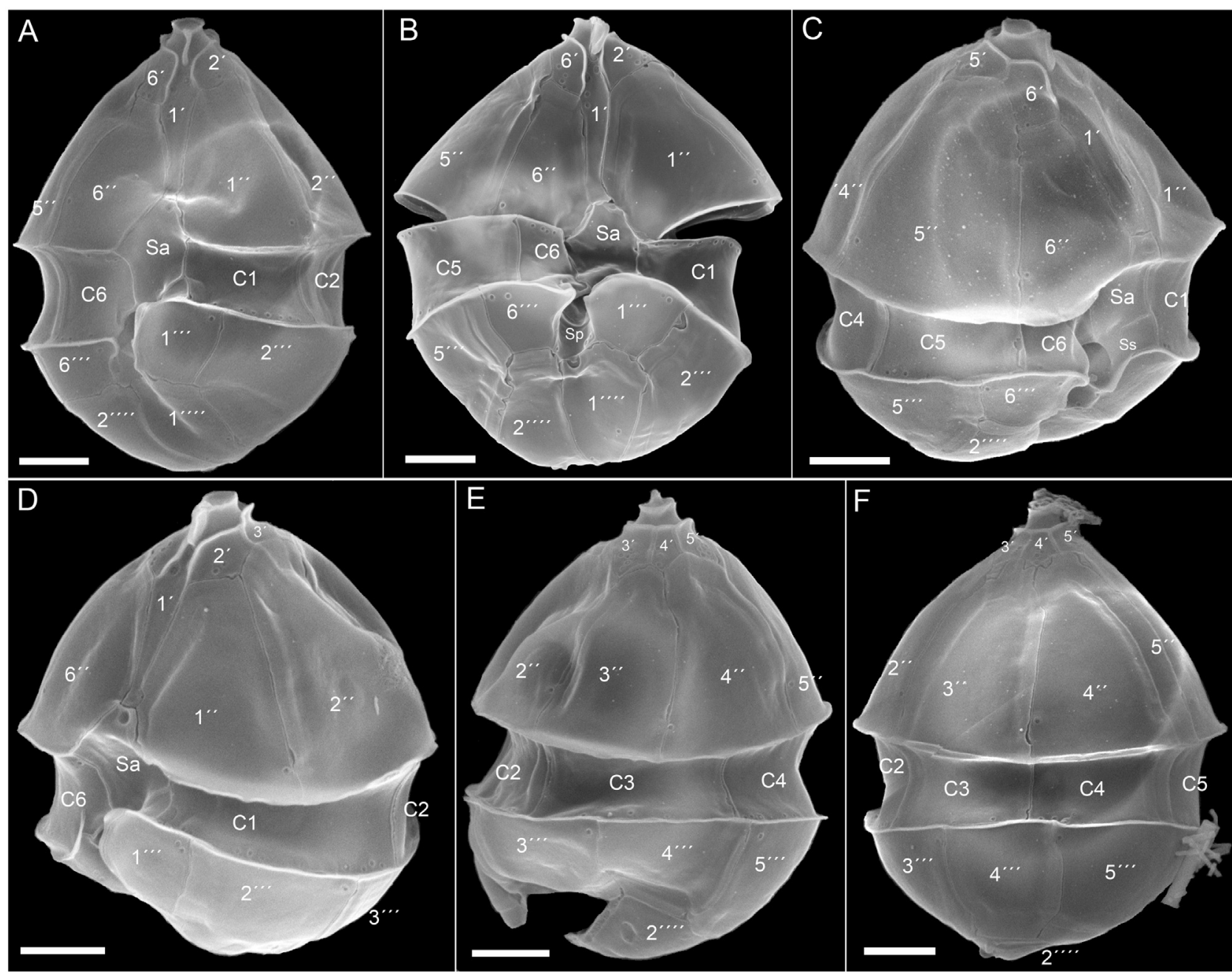

Fig. 4. Amphidoma languida (strain AND-A0920): SEM of different cells. (A-B) Ventral view. (C-D) Ventral-lateral view. $(\mathrm{E}-\mathrm{F})$ Dorsal view. Scale bars $=2 \mu \mathrm{m}$.

Biospin, Wissembourg, France), a dual ion source and Paracell analyzer cell (Boldin and Nikolaev, 2011). The samples were ionized by electrospray ionization in positive ion mode. Sample solutions were continuously infused using a syringe at a flow rate of $2 \mu \mathrm{L} \mathrm{min}^{-1}$. The detection mass range was set to $\mathrm{m} / z$ 150-3000. Ion accumulation time for each scan was set to $0.1 \mathrm{~s}$. Several scans were added for the final mass spectrum. Data sets were acquired with $4 \mathrm{MW}$ data points resulting in a resolving power of 450,000 at $\mathrm{m} / \mathrm{z} 400$. Spectra were zero-filled to process size of $8 \mathrm{M}$ data points before sine apodisation. Mass spectra were calibrated with arginine clusters using a linear calibration. A $10 \mu \mathrm{g} \mathrm{mL}^{-1}$ solution of arginine in 50\% methanol was used to generate the clusters. Ion accumulation time was set to several seconds for MS/ MS experiments for improved $\mathrm{S} / \mathrm{N}$ of the fragment mass peaks. The quadrupole isolation window was set to $0.5 \mathrm{Da}$ and collision energy was set to $30 \mathrm{eV}$.

\section{Results}

\subsection{Background information, sampling site}

The sampling period was characterized by an input of high salinity (36), cold $\left(14-16^{\circ} \mathrm{C}\right)$ water masses and by the occurrence of a DSP event causing closures of some shellfish production areas. Water samples were found to contain the known DSP producing species $D$. acuminata, $D$. acuta and $D$. caudata together with a number of other small, unidentified dinophycean species.

\subsection{Toxin analysis of mussels}

Shellfish samples revealed the presence of okadaic acid (OA), dinophysistoxin-2 (DTX-2) and pectenotoxin-2 (PTX-2) during the sampling period. The presence of these lipophilic toxins in the samples was confirmed by comparing the retention times in chromatograms and the fragmentation spectra with those of certified reference solutions. Analyses also revealed the presence of AZA-2 (Fig. 2A). In addition, a peak was detected with the pseudo-molecular mass of AZA-3, but not yielding the characteristic fragment ion $m / z 658$ of AZA-3 and that, consequently, could not be attributed to that toxin. Of the three AZA monitored (AZA-1, $-2,-3$ ), thus only the presence of AZA-2 was confirmed throughout the monitoring period as it was found in different species of molluscs (Cerastoderma edule, Chamelea gallina, Donax trunculus and Solen vagina). Over an extended period of time, the estimated AZA toxicities were above $80 \mu \mathrm{g}$ AZA-1 eq. $\mathrm{kg}^{-1}$ (i.e. half the EU regulatory level) and exceeded the EU regulatory level of $160 \mu \mathrm{g}$ AZA-1 eq. $\mathrm{kg}^{-1}$ in a number of cases, reaching maximum levels of $>500 \mu \mathrm{g}$ AZA-1 eq. $\mathrm{kg}^{-1}$ in Chamelea gallina and $>250 \mu \mathrm{g}$ AZA- 1 eq. $\mathrm{kg}^{-1}$ in Donax trunculus (Table 1 ). The ratio of AZA-2 to AZA-43, as 


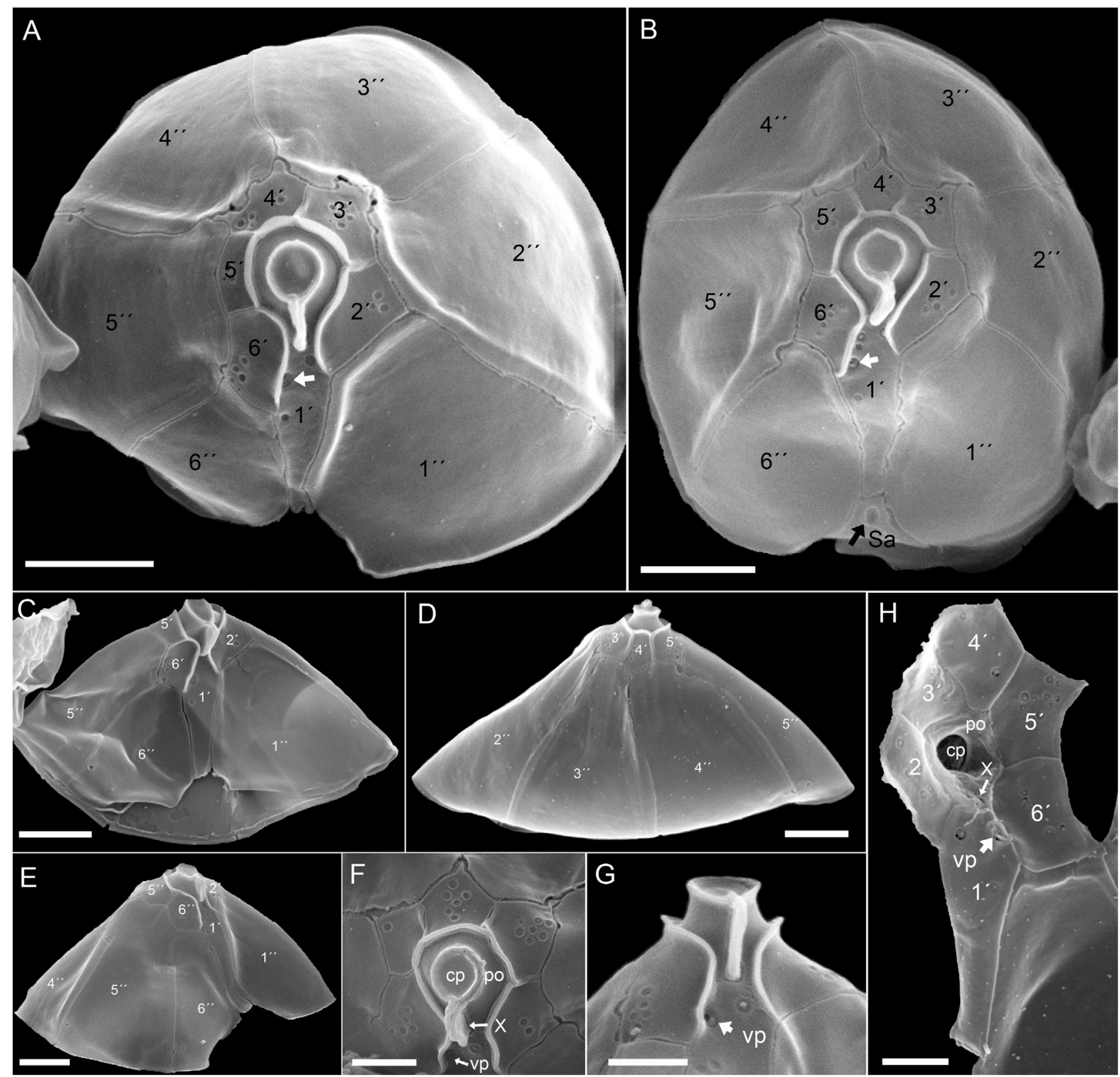

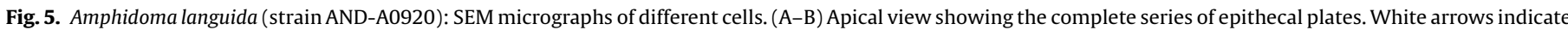

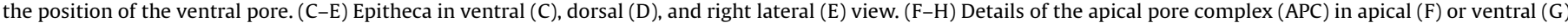
view. $(\mathrm{H}) \mathrm{APC}$ viewed interiorly of the cell. $\mathrm{po}=$ pore plate, $\mathrm{vp}=$ ventral pore; $\mathrm{x}=\mathrm{X}$-plate, $\mathrm{cp}=$ cover plate. $\mathrm{Scale}$ bars $=2 \mu \mathrm{m}(\mathrm{A}-\mathrm{E})$ or $=1 \mu \mathrm{m}(\mathrm{F}-\mathrm{H})$.

retroactively estimated in some selected shellfish samples, was quite variable and ranged from 11 to 1 .

\subsection{Algal culture screening for the presence of $A Z A$}

Screening of a total of five cultures revealed that one culture contained AZA-2 (for detailed analysis see below) and this isolate AND-A0920 was thus selected for a detailed morphological and molecular characterization and for a AZA profile determination.

\subsection{Morphological characterization of strain AND-A0920 by light and electron microscopy}

When positively identified as a source of AZA, initial microscopic observations indicated that the isolate ANDA0920 represented the species Amphidoma languida. This preliminary identification was based on size and shape, and particularly on the conspicuous swimming pattern visible at low magnification microscopy. Normally, cells moved slowly and performed sudden jumps irregularly. These jumps occurred when cells approached the bottom of the culture vessel or were stimulated by short vibrations. The cursory species designation then was confirmed by detailed light and electron microscopy.

Cells of Am. languida AND-A0920 were ovoid to slightly elliptical (Fig. 3), with a conical episome and a distinctly pointed apical pore. Cells were slightly variable in size (Fig. 3A) being $13.6 \pm 1.1 \mu \mathrm{m}$ in length (min 11.4-max 16.6; $\mathrm{n}=120$ ) and $10.5 \pm 0.8 \mu \mathrm{m}$ in width ( $\min 8.6-\max 12.2 ; \mathrm{n}=120$ ) and resulting in a mean length/width ratio of 1.3 . The episome was slightly larger than the hemispherical hyposome, which run out in a pointed antapex (Fig. 3D). The large chloroplast was mainly positioned in the episome but extended with lateral strands into the hyposome 

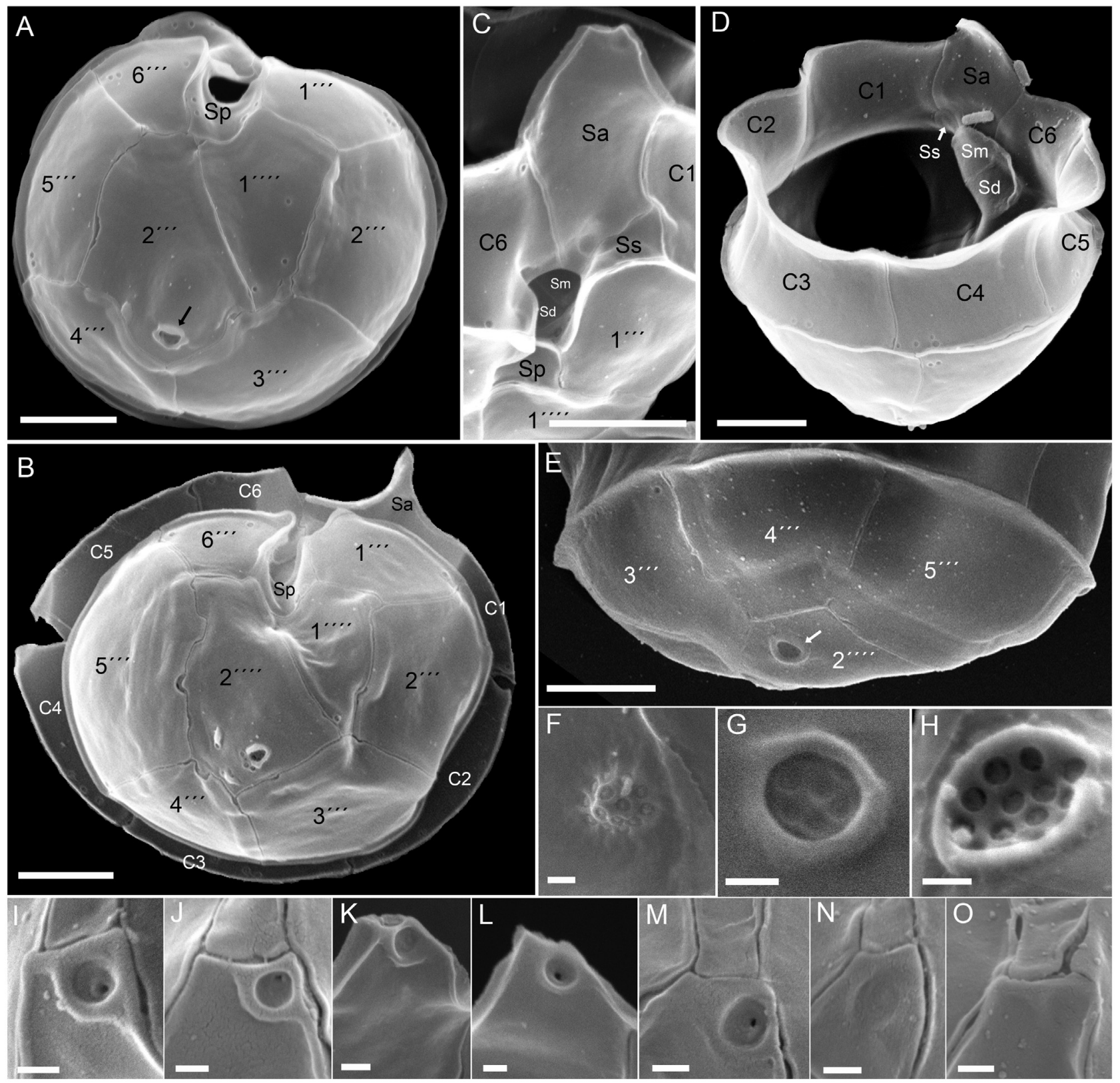

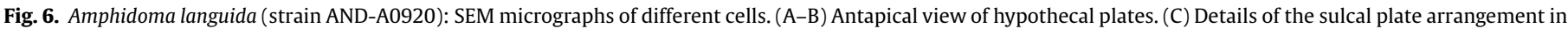

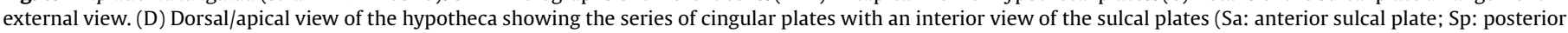

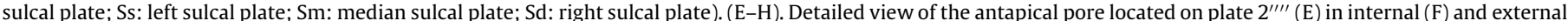
$(\mathrm{G}-\mathrm{H})$ view. (I-O) Detailed view of the anterior sulcal plate Sa showing different shapes of the ventral depression. Scale bars $=2 \mu \mathrm{m}(\mathrm{A}-\mathrm{E})$ or $0.2 \mu \mathrm{m}(\mathrm{F}-\mathrm{O})$.

Table 2

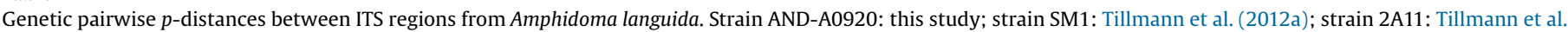
(2015).

\begin{tabular}{|c|c|c|c|c|c|c|c|c|c|}
\hline strain/ITS-clone & 2A11 ITS-clone 9 & 2A11 ITS-clone 10 & $\begin{array}{l}\text { AND-A0920 } \\
\text { ITS-clone a2 }\end{array}$ & $\begin{array}{l}\text { AND-A0920 } \\
\text { ITS-clone a7 }\end{array}$ & $\begin{array}{l}\text { AND-A0920 } \\
\text { ITS-clone a8 }\end{array}$ & $\begin{array}{l}\text { AND-A0920 } \\
\text { ITS-clone b5 }\end{array}$ & $\begin{array}{l}\text { AND-A0920 } \\
\text { ITS-clone b6 }\end{array}$ & $\begin{array}{l}\text { AND-A0920 } \\
\text { ITS-clone b7 }\end{array}$ & SM1 \\
\hline 2A11 ITS-clone 2 & 0 & 0.011 & 0.026 & 0.042 & 0.037 & 0.017 & 0.037 & 0.026 & 0.019 \\
\hline 2A11 ITS-clone 9 & & 0.011 & 0.026 & 0.042 & 0.037 & 0.017 & 0.037 & 0.026 & 0.019 \\
\hline 2A11 ITS-clone 10 & & & 0.026 & 0.042 & 0.037 & 0.017 & 0.037 & 0.026 & 0.016 \\
\hline AND-A0920 ITS-clone a2 & & & & 0.027 & 0.039 & 0.009 & 0.026 & 0.004 & 0.022 \\
\hline AND-A0920 ITS-clone a7 & & & & & 0.045 & 0.032 & 0.029 & 0.027 & 0.039 \\
\hline AND-A0920 ITS-clone a8 & & & & & & 0.032 & 0.034 & 0.041 & 0.037 \\
\hline AND-A0920 ITS-clone b5 & & & & & & & 0.032 & 0.009 & 0.017 \\
\hline AND-A0920 ITS-clone b6 & & & & & & & & 0.027 & 0.034 \\
\hline AND-A0920 ITS-clone b7 & & & & & & & & & 0.022 \\
\hline
\end{tabular}



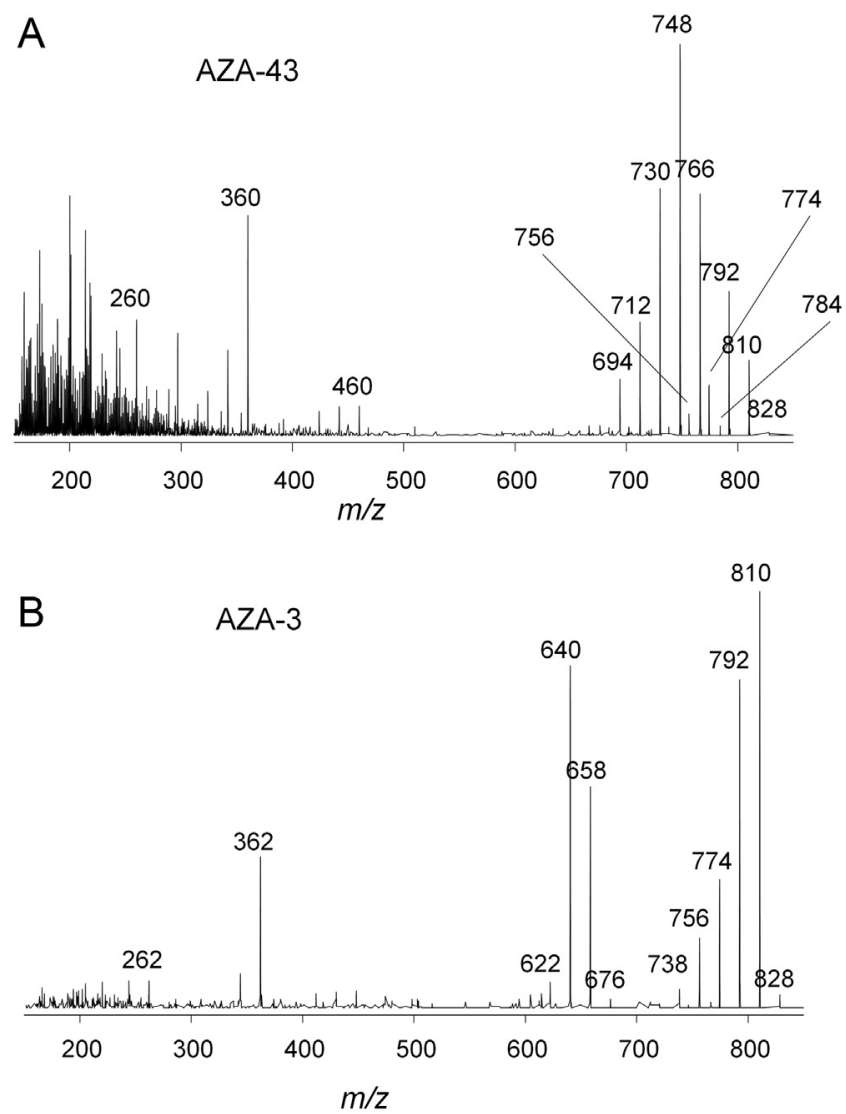

Fig. 7. Collision induced dissociation (CID) spectra of isobaric AZA-43 (A) and AZA-3 (B).

as well (Fig. 3E-F). Usually, a single large pyrenoid was centrally located in the episome (Fig. 3B, D, F). Rarely (but not quantified), cells with two pyrenoids were observed (Fig. 3G). If two pyrenoids were present, then they were both positioned in the episome. The spherical through ovoid nucleus was located in the posterior part of the cell being large and filling almost the entire hyposome (Fig. 3D).

The plate formula was determined by SEM as Po, cp, X, 6', 0a, 6"

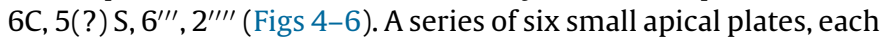
bearing a group of three through five small pores, surrounded the rounded apical pore plate (Fig. 5A-B). The round through ellipsoid apical pore was covered by a cover plate and connected to the first apical plate by a finger-like protrusion as a three-dimensional outgrowth of the small X-plate (Fig. 5F-H). A large ventral pore was identified anteriorly on the right side of the first apical plate

Table 3

Typical AZA group fragments, exact masses and elemental composition of AZA1 and AZA-43.

\begin{tabular}{|c|c|c|c|c|c|}
\hline & \multicolumn{3}{|c|}{ AZA-43 $\mathrm{m} / \mathrm{z}$} & \multicolumn{2}{|l|}{ AZA- $1 \mathrm{~m} / \mathrm{z}$} \\
\hline & Observed & Composition & $\pm \mathrm{ppm}$ & Observed & Composition \\
\hline Group-1 & 828 & $\mathrm{C}_{46} \mathrm{H}_{70} \mathrm{NO}_{12}$ & 0.1 & 842 & $\mathrm{C}_{47} \mathrm{H}_{72} \mathrm{NO}_{12}$ \\
\hline Group-1 - $\mathrm{CO}_{2}$ & 784 & $\mathrm{C}_{45} \mathrm{H}_{70} \mathrm{NO}_{10}$ & 0.1 & - & - \\
\hline Group-2 & - & - & - & 672 & $\mathrm{C}_{38} \mathrm{H}_{58} \mathrm{NO}_{12}$ \\
\hline Group-3 & 460 & $\mathrm{C}_{27} \mathrm{H}_{42} \mathrm{NO}_{5}$ & 0.2 & 462 & $\mathrm{C}_{27} \mathrm{H}_{44} \mathrm{NO}_{5}$ \\
\hline Group-4 & 360 & $\mathrm{C}_{22} \mathrm{H}_{34} \mathrm{NO}_{3}$ & 0.1 & 362 & $\mathrm{C}_{22} \mathrm{H}_{36} \mathrm{NO}_{3}$ \\
\hline Group-5 & 260 & $\mathrm{C}_{16} \mathrm{H}_{22} \mathrm{NO}_{2}$ & 0.1 & 262 & $\mathrm{C}_{16} \mathrm{H}_{24} \mathrm{NO}_{2}$ \\
\hline Group-6 & 166 & $\mathrm{C}_{10} \mathrm{H}_{16} \mathrm{NO}$ & 0.1 & 168 & $\mathrm{C}_{10} \mathrm{H}_{18} \mathrm{NO}$ \\
\hline
\end{tabular}

Table 4

Amphidoma languida AND-A0920, AZA cell quota of different culture harvests.

\begin{tabular}{lllll}
\hline cell density & $\mathrm{mL}$ & growth phase & $\begin{array}{l}\text { AZA-2 } \\
\text { fg cell }\end{array}$ & $\begin{array}{l}\text { AZA-43 } \\
\text { fg cell }^{-1}\end{array}$ \\
\hline cells $\mathrm{mL}^{-1}$ & harvested & & & \\
\hline 32,221 & 40 & early stationary & 5.2 & 0.9 \\
12,340 & 400 & exponential & 16.6 & 4.0 \\
34,459 & 15 & early stationary & 14.6 & 2.9 \\
23,150 & 50 & late exponential & 15.5 & 4.2 \\
22,752 & 50 & late exponential & 24.1 & 5.0 \\
4,536 & 50 & exponential & 8.8 & 2.9 \\
\hline
\end{tabular}

(Fig. 5A-B, F-H). The six precingular plates were of comparable size and smooth except for one or two small pores per plate invariably located close to the cingulum at the plate sutures (Fig. 5C-E). The most dorsal plate $3^{\prime \prime}$ was free of pores. Likewise, the dorsal postcingular plate $4^{\prime \prime \prime}$ was free of pores, whereas the other of the six postcingular plates had one or very few pores located close to the cingulum at the plate sutures (Fig. 6). As a very distinctive feature, the larger of the two antapical plates had a large antapical pore close to the junction of plates $3^{\prime \prime \prime}$ and $4^{\prime \prime \prime}$ (Fig. 6A, B, E-H). This structure, surrounded by a broad rim, was an inwardly domed field of a number of 10-15 small pores. Six cingular plates of comparable size (Fig. 6D) and five sulcal plates with a characteristic three dimensional structure (Fig. 6C-D) were present.

For most cells, a depression with a roundish outline was visible on the anterior tip of the anterior sulcal plate (Fig. 5B, black arrow, Fig. 6I-O). Typically, it was located at the left upper margin of the Sa plate and was surrounded by a broad rim. As compiled in Figures $6 \mathrm{I}-\mathrm{O}$, the shape and characteristic of this "ventral depression" was variable among cells ranging from distinctly developed to faintly expressed and in a few cases, it was almost indiscernible. Unlike a pore this depression did not seem to cut through the thecal plate, although a small central cavity was visible occasionally.

\subsection{Molecular characterization}

Eight new rRNA sequences were submitted to GenBank and are available as entries KX671036 - KX671043. All sequences derived from strains (including ITS-clones) assigned to Am. languida (i.e., AND-A0920: this study; SM1: Tillmann et al., 2012a,b; 2A11: Tillmann et al., 2015) constituted a monophyletic group supported by maximal statistical values (data not shown). Internal resolution of the clade, however, was poor and did not show any structure. Within Am. languida, ITS pairwise distances were considerable (Table 2) ranging from 0 to 0.045 . Compensatory base changes could not be observed.

\subsection{Azaspiracid analysis of Amphidoma languida AND-A0920}

Based on selected reaction monitoring (SRM) experiments the extract of Am. languida AND-A0920 showed two peaks: an early eluting peak with transition $m / z 828>810$ at the retention time of $9.25 \mathrm{~min}$ and a later eluting peak with transition $\mathrm{m} / \mathrm{z} 856>838$ at $10.01 \mathrm{~min}$ (Fig. 2B). In order to test the presence of any other AZArelated compounds, precursor ion scans of the three typical AZA group-4 fragments $\mathrm{m} / \mathrm{z} 348,360$, and 362 were performed. Whereas the precursor scan of $\mathrm{m} / z 348$ did not give any peak, the precursor experiments of $m / z 360$ and $m / z 362$ resulted only in the peaks of $m / z 828$ and $m / z 856$, respectively, thus confirming the SRM experiment and evidencing that no other AZA was present in the sample. To further investigate the identity of the two AZA found in this sample, collision induced dissociation (CID) spectra of both compounds were recorded. Collision induced dissociation spectrum and retention time of $m / z 856$ were identical to those of 
AZA-2 confirming its identity (data not shown). The CID spectrum of $m / z 828$ (Fig. 7) has not been reported in the literature to date. In continuation of the current nomenclature of new AZA using serial numbers this compound will be named AZA-43.

In order to further confirm the elemental composition of AZA43 and its fragments, high resolution mass measurements were performed (Table 3 ). As in all CID spectra of AZA, the water losses from the pseudo-molecular ion $[\mathrm{M}+\mathrm{H}]^{+}$were also present in the spectrum of $A Z A-43$, but the loss of $\mathrm{CO}_{2}$ from the $[\mathrm{M}+\mathrm{H}]^{+}$ion followed by several water losses was more intensive. Another characteristic feature of the CID spectrum of AZA-43 consisted in the $m / z$ values of fragment groups-3 -6 , which were each $2 \mathrm{Da}$ smaller than those of the parent compound AZA-1 (Fig. 7, Table 3).

AZA cell quota was determined for a number of cultures harvested at different cell densities representing different stages of growth (Table 4). AZA-2 was 3 to 6 times more abundant than AZA43 and ranged from 5.2 through $24.1 \mathrm{fg} \mathrm{cell}^{-1}$. There was no clear relation of cell quota to the culture growth phase (Table 4).

\section{Discussion}

\subsection{Distribution of AZA}

This first AZA report in shellfish from southern Spain indicates that the compounds, as well as the producing organisms, are not restricted to Ireland and the North Sea but are present throughout the entire Atlantic coast of southern Europe. The first report of AZA from southern Europe came from Braña Magdalena et al. (2003). They analyzed blue mussels from Galicia and reported $240 \mu \mathrm{g}$ AZA $\mathrm{kg}^{-1}$. Notwithstanding, numerous analyses carried out after that date by several laboratories have not found the presence of AZA in bivalves or plankton from the area (Juan Blanco, unpublished data; José Franco, CSIC-IEO, pers. comm.) and in the very few cases, in which they were detected (at the north coast of Galicia, far from the Ría de Vigo), only AZA-2 was found and at very low levels (around $3 \mu \mathrm{g} \mathrm{kg}^{-1}$ ) (Fabiola Arévalo, INTECMAR, pers. comm.). Further south AZA were monitored in Portugal and the Iberian Peninsula since 2002, but were unambiguously identified not before 2006 (Vale et al., 2008). The authors detected AZA at several sampling sites along the Portuguese coast in a number of shellfish species, including common cockle (Cerastoderma edule), oysters (Crassostrea spp.), blue mussel (Mytilus galloprovincialis), clams (Ruditapes decusssatus), Venerupis senegalensis, and razor clams (Solen marginatus), but AZA levels in Portugal were rather low (1.6$\left.6.1 \mu \mathrm{g} \mathrm{kg}^{-1}\right)$. Further south the Atlantic coast in northwestern Africa (Morocco), time series of algal toxins in summer 2004 and 2005 , respectively, revealed peak values up to $350 \mu \mathrm{g} \mathrm{kg}^{-1}$ and $650 \mu \mathrm{g} \mathrm{kg}^{-1}$ in the digestive gland of blue mussels (Taleb et al., 2006). Noteworthy, toxins are highly concentrated in the digestive gland but not as much in other shellfish tissue (Hess et al., 2005; Jauffrais et al., 2012) and thus, such values cannot directly be compared with the EU regulatory limit. In summer 2006, low levels of AZA (up to $6 \mu \mathrm{g} \mathrm{kg}^{-1}$ edible tissue) were reported from the same area about $180 \mathrm{~km}$ south of Casablanca (Elgarch et al., 2008).

Thus, the presence of AZA along the Atlantic coast of southern Europe and northern Africa was shown sporadically, but levels above the EU regulatory limit were rarely found. The present results from Andalusia now show that AZA contamination episodes above the EU regulatory level in fact occur in southern Europe and may also affect the growing shellfish industry. The province of Huelva suffers mainly from annual blooms of dinophytes such as $D$. acuminata occuring in spring and summer. During the episode of shellfish toxicity in 2009 in Andalusia described here, $D$. acuminata was accompanied by $D$. acuta and $D$. caudata, causing closures of production areas due to high toxin content. Around mid of July, AZA-2 appeared and lasted with a slow process of depuration throughout August. High toxin concentrations caused closures of production areas comprising $122 \mathrm{~km}$ of coast line and lasting for six weeks. Closures impeded the commercialization of certain species of bivalves, but no incidence on human health was reported.

\subsection{The causative species}

Azaspiracid profiles in the Andalusian shellfish samples were different from those found in Ireland and other North European areas. There, AZA-1 and AZA-2 are the dominating compounds in shellfish and plankton samples (James et al., 2002; Amzil et al., 2008; Krock et al., 2009) corresponding to the toxin profile of Azadinium spinosum (Krock et al., 2009) as the presumably most important AZA-producing species in the area (Salas et al., 2011). The AZA profile in Andalusian shellfish, with a lack of AZA-1, the predominance of AZA-2, and the presence of a second compound (identified here as the new AZA-43), thus provides compelling evidence for the involvement of another AZA source organism.

Both morphological and rRNA sequence data leave no doubt that isolate AND-A0920 is correctly determined as Am. languida exhibiting a new AZA profile. The conspicuous swimming behaviour, the plate formula, the arrangement, size, and shape of thecal plates, the location of a ventral pore on plate $1^{\prime}$, the location of a large antapical pore on plate $2^{\prime \prime \prime \prime}$, as well as the arrangement of small pores on the plates correspond to the original description of Am. languida (Tillmann et al., 2012a). The roundish depression on the anterior tip of the anterior sulcal plate (see Fig. 6I-O) is not explicitly noted in the protologue. It is, however, visible in images of strain SM1 (Tillmann et al., 2012a: their Figs. 2B and S1D), from which the holotype has been prepared, and is also described for a strain of Am. languida isolated from the Irminger Sea (Tillmann et al., 2015). The observation of such a depression in the third strain of the species indicates that this is a characteristic morphological feature. It is, however, not present in all specimens and thus seems to be of little diagnostic value.

Analysis of rRNA sequence data confirms the morphological evaluation, and all sequence data available for the three strains of Am. languida indicate the existence of a monophyletic unit. The new isolate AND-A0920 (derived from a single cell), however, shows a relatively large intragenomic variability of ITS clones exhibiting $p$-distances up to 0.045 . This range has been also shown

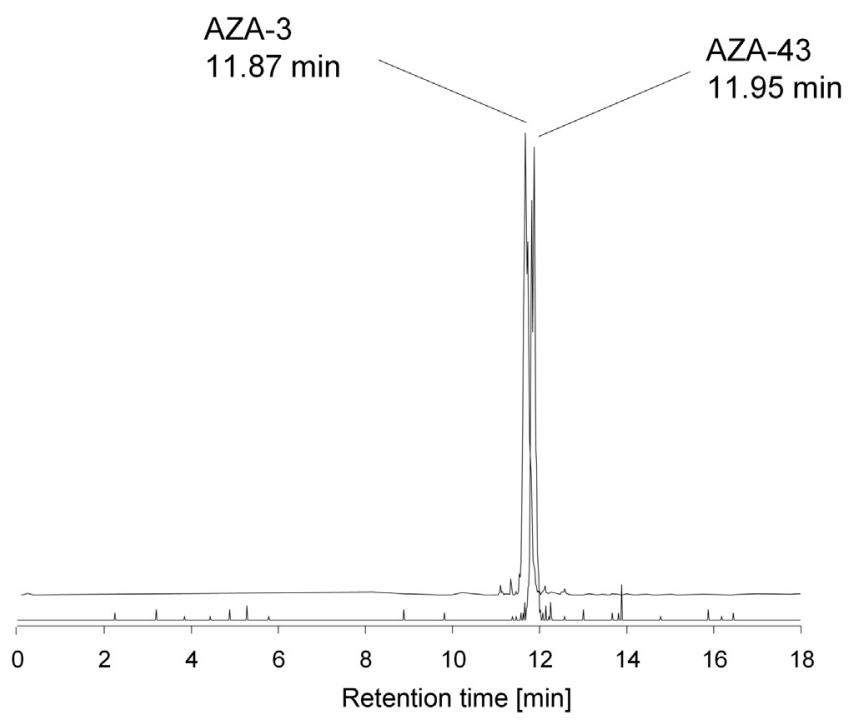

Fig. 8. Selected ion chromatograms $(m / z 828>810)$ of AZA-3 and AZA-43. 
for individual strains assigned to $A z$. dexteroporum from discrete origins (Tillmann et al., 2015). Such values exceed the threshold of 0.040 proposed by Litaker et al. (2007) to differentiate between a single and different species based on ITS sequence data. Absolute values can always be not more than an approximation for biological phenomena, and the Amphidomataceae may exhibit larger intragenomic variability than other dinophyte groups. It cannot be ruled out that the three strains of Am. languida represent several species, but a single reproductively isolated unit with a rather high molecular variability is more likely to assume in a comparative approach. A reliable assessment of the species status is only possible with further research including, for example, breeding experiments.

The Spanish records of Am. languida represent a significant range expansion of the species, which yet has been described by isolates from the Irish coast (Salas et al., 2011) and from the Irminger Sea (Tillmann et al., 2015). Additional SEM images of field samples indicate a wide distribution with records of Am. languida covering the East Atlantic (Lewis and Dodge, 1990; Saint-Pierre and Miquelon: Elisabeth Nézan pers. comm.), as well as the Black Sea (Nihayet Biszel, pers. comm.). Moreover, cells most likely determinable as Am. languida have been observed in SEM from a sample collected at the open West-Indian Ocean (Consuelo Carbonell, pers. comm.). The species Am. languida is also identified by SEM of bloom samples from the Argentinean shelf (Tillmann and Akselman, 2016). Thus, the species seems to be widely distributed, and more sequence data are needed to fully evaluate the evolutionary relationships of such different distribution records.

\subsection{Toxins}

The species Am. languida is one of four (out of 19 described) species assigned to Amphidomataceae, which have been identified to produce AZA (Krock et al., 2012; Percopo et al., 2013). With the limited number of strains at hand, it is not clear whether and to which extent AZA production is a species-specific and consistent phenotypic trait. For example, $A z$. dexteroporum from the Mediterranean is shown to produce toxins (Percopo et al., 2013), whereas no AZA is detectable in a Subarctic strain (Tillmann et al., 2015 ). For Az. poporum, AZA production is shown for various strains around the globe (Krock et al., 2012; Gu et al., 2013; Tillmann et al., 2016), but a few strains among other toxigenic isolates from China are described without any detectable AZA (Krock et al., 2014). On the other hand, all four available strains of $A z$. spinosum produce AZA and also exhibit the same AZA profile consisting of AZA-1, -2, and -33 (Tillmann et al., 2012b). For Am. languida, AZA are found in each of the two previously available strains from Ireland and Iceland. Azaspiracid detection in a third strain of Am. languida presented here thus might indicate that AZA is a stables specific trait of the species.

The toxin cell quota determined here for the Spanish strain is in the same range of about $5-20 \mathrm{fg} \mathrm{cell}^{-1}$ usually reported for other AZA producing species (Tillmann et al., 2014b). A maximum value of $200 \mathrm{fg} \mathrm{cell}^{-1}$ for $A z$. spinosum grown at low temperature $\left(10^{\circ} \mathrm{C}\right)$ is reported (Jauffrais et al., 2013), but corresponding laboratory experiments studying environmental effect on AZA cell quota of Am. languida are still lacking.

Noteworthy, the AZA profile of the Andalusian strain is significantly different from the Irish and Iceland strains of $A m$. languida producing AZA-38 and -39 (Krock et al., 2012; Tillmann et al., 2015). These compounds are missing a methyl group in the I ring (named "348-type") and thus vary compared to AZA-2 and AZA-43 produced by the Spanish isolate. In view of these different toxin profiles from strains of different origin, it is tempting to speculate about a potential chemotaxonomic use of the toxin profiles but for a sound evaluation, the characterization of AZA profiles of many more isolates is needed.

The presence and predominance of AZA-2 for the Spanish strain of Am. languida is interesting and important for several reasons. It indicates that AZA-2 is the most widespread compound produced by the algal source organisms, as it is found in three different species: Az. spinosum (Krock et al., 2009), Az. poporum (Gu et al., 2013; Tillmann et al., 2016), and Am. languida (this study). This provides additional evidence for the close relationship between Azadinium and Amphidoma not only from a phylogenetic perspective, but also on a metabolic basis. Moreover, AZA-2 is reported to be 8.3 fold more cytotoxic compared to AZA-1 (Twiner et al., 2012), although recent research indicate that AZA-2 is less toxic compared to AZA-1 both by oral and intraperitoneal application in the mouse assay (Kilcoyne et al., 2014). Finally, AZA-2 is determined as the predominant AZA in shellfish of the southern Atlantic coast before (Taleb et al., 2006; Vale et al., 2008). This finding is the main difference to areas more to the North and has been discussed as evidence for different local AZA source organisms (Taleb et al., 2006), which can be confirmed with the identification of Am languida producing AZA-2.

In addition to AZA-2, the Spanish strain produces a novel AZA analogue. This new compound, namely AZA-43, has the same mass as AZA-3. The mass fragment $m / z 658$ of AZA-3, however, is absent in AZA-43 indicating differences between the two compounds based on a more thorough analysis of the corresponding peaks (Fig. 7). Collision induced dissociation (CID) spectra of both compounds display typical AZA features such as multiple water losses from the pseudo-molecular ions and the higher mass fragments and the occurrence of the characteristic AZA group fragments. Nevertheless, there are discrete differences between the CID spectra of both compounds. The most obvious difference is the complex pseudo-molecular ion cluster of AZA-43. This cluster of AZA-3 consists of subsequent water losses only, whereas AZA43 additionally shows the elimination of $\mathrm{CO}_{2}$ followed by several water losses, which is even more dominant than the pure water losses. The elimination of $\mathrm{CO}_{2}$ from AZA is relatively rare (Krock et al., 2012). Another obvious difference is the absence of the group- 2 fragment in AZA-43 and a shift of group- 3 to -6 fragments to 2 Da smaller masses as in AZA-1, -2 , and -3 (Table 3). High resolution mass spectrometric measurements clearly indicated that there is an unsaturation in the $\mathrm{H}$, I ring system of AZA-43 with respect to the classical $A Z A$, such as $A Z A-1,-2$, or -3 . As the characteristic group- 4 fragment of AZA-43 differs from the classical 362-type AZA (AZA-1 through -12) and from the recently described 348-type AZA (AZA-36 and -37, Krock et al., 2015), a new class is proposed: 360-type AZA with the above described unsaturation.

It is noteworthy that new AZA-43 and AZA-3, which is a shellfish metabolite of AZA-1 (Jauffrais et al., 2012), are not only isobaric (i.e., possess the same molecular mass), but also have very close retention times (Fig. 8) implying the risk of misidentification. Even though AZA-3 is considered a shellfish metabolite, it eventually has been reported form planktonic or passive adsorption samples (James et al., 2003; Fux et al., 2009), possibly beause of such misidentification. Likewise, small amounts of AZA-3 were reported to accompany the AZA-2 records in African shellfish (Taleb et al., 2006), even when AZA-1 was completely absent. This is further evidence that Am. languida (with the same toxin profile) might have been responsible of these shellfish contamination in Africa as well. The same mass and similar retention time of AZA-43 and AZA-3 is an important issue especially in sea food safety and control (AZA-3 but not AZA-43 is regulated by European legislation). Both AZA can occur in shellfish, the latter as seen in the Andalusian samples, and AZA-3 in mussels from other oceanographic regions (Braña Magdalena et al., 2003; Furey et al., 2003). 


\subsection{Implications}

The first Andalusian case of AZA contamination of shellfish above the EU regulatory limit reported here clearly reveals the risk of azaspiracid poisoning (AZP) for this area and more generally for the Atlantic coast of the Iberian Peninsula and northern Africa. Thus, the risk potential of shellfish contamination in the area is expanded beyond the regularly appearing threat of Dinophysis toxins. Since 2009, however, AZA concentrations in shellfish have never been above the detection limit in Andalusia. Moreover, special attention has been paid to the detection of Am. languida and relatives based on light microscopy in the course of the local monitoring systems. In line with a lack of AZA in mussel since 2009, Amphidomataceae have not been detected again in Andalusia. Nevertheless, it is well known that the occurrence and development of plankton, and especially of particular plankton species, can be sporadic, intermittent, and generally difficult to predict, especially in light of the continuously ongoing environmental and climate change, which may lead to unexpected interannual variations and exceptional bloom events. The consideration of AZA-43 and Am. languida as new target toxin and species in the monitoring systems of the area is thus needed and should include both analyzing the toxins in shellfish and the presence of the organisms in the water.

With respect to AZA, the toxicity of AZA-2 as well as its degradation and conversion in bivalves is well known (Hess et al., 2014; Twiner et al., 2014). This knowledge, however, is completely lacking for the new compound AZA-43, whose substantial contribution to total AZA may imply a risk for human health. Future studies thus should address a further characterization of this compound including structural elucidation and, most importantly, toxicity, and bioconversion in shellfish. Additional attention should be given to the detection and quantification of AZA-43 also in monitoring programs of nearby areas, such as Portugal and Morocco, which might include a retrospective analysis of archived shellfish samples.

\section{Acknowledgements}

Thanks to Wolfgang Drebing (AWI Bremerhaven) for technical support in AZA analysis as well as to Nancy Kühne (AWI Bremerhaven) for DNA extraction and sequencing. Financial support was provided by the PACES research program of the Alfred Wegener Institute as part of the Helmholtz Foundation initiative in Earth and Environment.[SS]

\section{Appendix A. Supplementary data}

Supplementary data associated with this article can be found, in the online version, at http://dx.doi.org/10.1016/j.hal.2016.12.001.

\section{References}

Álvarez, G., Uribe, E., Ávalos, P., Mariño, C., Blanco, J., 2010. First identification of azaspiracid and spirolides in Mesodesma donacium and Mulinia edulis from Northern Chile. Toxicon 55, 638-641.

Amzil, Z., Sibat, M., Royer, F., Savar, V., 2008. First report on azaspiracid and yessotoxin groups detection in French shellfish. Toxicon 52, 39-48.

Boldin, I.A., Nikolaev, E.N., 2011. Fourier transform ion cyclotron resonance cell with dynamic harmonization of the electric field in the whole volume by shaping of the excitation and detection electrode assembly. Rapid Commun. Mass Spectrom. 25, 122-126.

Braña Magdalena, A., Lehane, M., Krys, S., Fernández, M.L., Furey, A., James, K.J., 2003. The first identification of azaspiracids in shellfish from France and Spain. Toxicon 42, 105-108.

Dahl, E., Lindahl, O., Paasche, E., Throndsen, J., 1989. The Chrysochromulina polylepis bloom in Scandinavian waters during spring 1998. In: Cosper, E.M., Bricelj, V.M. Carpenter, E.J. (Eds.), Novel Phytoplankton Blooms: Causes and Impacts of Recurrent Brown Tides and Other Unusual Blooms. Springer Verlag, Berlin, pp. $383-405$
EFSA, 2009. Scientific Opinion of the Panel on Contaminants in the Food Chain on a request from the European Commision on Marine Biotoxins in ShellfishSummary on regulated marine biotoxins. EFSA J. 1306, 1-23.

Elgarch, A., Vale, P., Rifai, S., Fassouane, A., 2008. Detection of diarrheic shellfish poisoning and azaspiracid toxins in Moroccan mussels: comparison of the LCMS method with the commercial immunoassay kit. Mar. Drugs 6, 587-594.

Fernández, L., Gordillo, M., Ocaña, M.A., Mamán, L., Jaén, D., Fernández, R., Czerwinski, I., Márquez, I., 2009. Efecto de la presencia de Dinophysis sobre los niveles de toxinas lipofílicas en moluscos del Golfo de Cádiz. X Reunião Ibérica, Fitoplâncton Tóxico e Biotoxinas, Lisboa.

Fernández, R., Mamán, L., Jaén, D., Díaz, C.F., Jurado, J.A., Czerwinski, I., Márquez, I. 2010. Resultados del seguimiento de fitoplancton tóxico en las zonas de producción de Andalucía en los años 2007 y 2008. In: Costa, P.R., Rodrigues, B. M., Palma, S.M., AS e Moita, M.T. (Eds.), Algas tóxicas e biotoxinas nas águas da Península Ibérica-2009. IPIMAR, Lisboa, Portugal, pp. 36-44.

Furey, A., Moroney, C., Braña Magdalena, A., Sáez, M.J.F., Lehane, M., James, K.J., 2003. Geographical, temporal, and species variation of the polyether toxins azaspirazids, in shellfish. Environ. Sci. Technol. 37, 3078-3084.

Fux, E., Biréx, R., Hess, P., 2009. Comparative accumulation and composition of lipophilic marine biotoxins in passive samplers and in mussels (M. edulis) on the west coast of Ireland. Harmful Algae 8, 523-537.

Gerssen, A., Mulder, P.P.J., McElhinney, M.A., deBoer, J., 2009. Liquid chromatography-tandem mass spectrometry method for the detection of marine lipophilic toxins under alkaline conditions. J. Chromatogr. 1216, 1421-1430.

Gu, H., Luo, Z., Krock, B., Witt, M., Tillmann, U., 2013. Morphology: phylogeny and azaspiracid profile of Azadinium poporum (Dinophyceae) from the China Sea. Harmful Algae 21-22, 64-75.

Guillard, R.R.L., Hargraves, P.E., 1993. Stichochrysis immobilis is a diatom, not a chrysophyte. Phycologia 32, 234-236.

Hall, T., 1999. BioEdit: a user-friendly biological sequence alignment editor and analysis program for Windows 95/98/NT. Nucleic Acids Sym. Ser. 41, 95-98.

Hallegraeff, G., 2014. Harmful algae and their toxins: progress, paradoxes and paradigm shifts. In: Rossini, G.P. (Ed.), Toxins and Biologically Active Compounds from Microalgae. CRC Press, Boca Raton, pp. 3-20.

Hess, P., Nguyen, L., Aasen, J., Keogh, M., Kilcoyne, J., McCarron, P., Aune, T., 2005. Tissue distribution, effects of cooking and parameters affecting the extraction of azaspiracids from mussels, Mytilus edulis, prior to analysis by liquid chromatography coupled to mass spectrometry. Toxicon 46, 62-71.

Hess, P., McCarron, P., Krock, B., Kilcoyne, J., Miles, C.O., 2014. Azaspiracids: chemistry, biosynthesis, metabolism, and detection. In: Botana, L.M. (Ed.), Seafood and Freshwater Toxins. CRC Press, Boca Raton, USA, pp. 799-821.

Jaén, D., Fernández, R., Mamán, L., Rivera, M.C., 2001. Seguimiento de fitoplancton tóxico en la costa andaluza durante los años 1999 y 2000. VII Reunión Ibérica Sobre Fitoplancton tóxico Y Biotoxinas. Consellería De Agricultura. Pesca y Alimentación, Generalitat Valenciana.

James, K.J., Furey, A., Lehane, M., Ramstad, H., Aune, T., Hovgaard, P., Morris, P. Higman, W., Satake, M., Yasumoto, T., 2002. First evidence of an extensive northern European distribution of azaspiracid poisoning (AZP) toxins in shellifish. Toxicon 40, 909-915.

James, K.J., Moroney, C., Roden, C., Satake, M., Yasumoto, T., Lehane, M., Furey, A., 2003. Ubiquitous benign alga emerges as the cause of shellfish contamination responsible for the human toxic syndrome, azaspiracid poisoning. Toxicon 41 , 145-154.

Jauffrais, T., Marcaillou, C., Herrenknecht, C., Truquet, P., Séchet, V., Nicolau, E., Tillmann, U., Hess, P., 2012. Azaspiracid accumulation, detoxification and biotransformation in blue mussels experimentally fed Azadinium spinosum (Dinophyceae). Toxicon 60, 582-595.

Jauffrais, T., Séchet, V., Herrenknecht, C., Truquet, P., Veronique, S., Tillmann, U., Hess, P., 2013. Effect of environmental and nutritional factors on growth and azaspiracid production of the dinoflagellate Azadinium spinosum. Harmful Algae $27,138-148$

Keller, M.D., Selvin, R.C., Claus, W., Guillard, R.R.L., 1987. Media for the culture of oceanic ultraphytoplankton. J. Phycol. 23, 633-638.

Kilcoyne, J., Jauffrais, T., Twiner, M.J., Doucette, G.J., Aasen, J.A., Sosa, S., Krock, B., Séchet, V., Nulty, C., Salas, R., Clarke, D., Geraghty, J., Duffy, C., Foley, B., John, U., Quilliam, M.A., McCarron, P., Miles, C.O., Silke, J., Cembella, A., Tillmann, U., Hess, P., 2014. Azaspiracids-Toxicological Evaluation, Test Methods and Identification of the Source Organisms (ASTOX II). Technical Report. Marine Institutem Galway, Ireland (ISSN:2009-3195. 188 pp).

Krock, B., Tillmann, U., John, U., Cembella, A.D., 2009. Characterization of azaspiracids in plankton size-fractions and isolation of an azaspiracidproducing dinoflagellate from the North Sea. Harmful Algae 8, 254-263.

Krock, B., Tillmann, U., Voß, D., Koch, B.P., Salas, R., Witt, M., Potvin, É., Jeong, H.J., 2012. New azaspiracids in Amphidomataceae (Dinophyceae): proposed structures. Toxicon 60, 830-839.

Krock, B., Tillmann, U., Alpermann, T.J., Voß, D., Zielinski, O., Cembella, A., 2013. Phycotoxin composition and distribution in plankton fractions from the German Bight and Western Danish Coast. J. Plankton Res. 35, 1093-1108.

Krock, B., Tillmann, U., Witt, M., Gu, H., 2014. Azaspiracid variability of Azadinium poporum a (Dinophyceae) from the China Sea. Harmful Algae 36, 22-28.

Krock, B., Tillmann, U., Potvin, É., Jeong, H.J., Drebing, W., Kilcoyne, J., Al-Jorani, A., Twiner, M.J., Göthel, Q., Köck, M., 2015. Structure elucidation and in vitro toxicity of new azaspiracids isolated from the marine dinoflagellate Azadinium poporum. Mar. Drugs 13, 6687-6702.

López-Rivera, A., O’Callaghan, K., Moriarty, M., O'Driscoll, D., Hamilton, B., Lehane, M., James, K.J., Furey, A., 2010. First evidence of azaspiracids (AZAs): a family of 
lipophilic polyether marine toxins in scallops (Argopecten purpuratus) and mussels (Mytilus chilensis) collected in two regions of Chile. Toxicon 55, 692701.

Lewis, J., Dodge, J.D., 1990. The use of the SEM in dinoflagellate taxonomy. In: Claugher, D. (Ed.), Scanning Electron Microscopy in Taxonomy and Functional Morphology, Vol. 41. Clarendon Press, The Systematics Association, Special, Oxford, pp. 125-148.

Lindahl, O., 1986. A Dividable Hose for Phytoplankton Sampling. International Council for the Exploration of the sea (ICES) (C.M. 1986/L:26, annex III).

Litaker, R.W., Vandersea, M.W., Kibler, S.R., Reece, K.S., Stokes, N.A., Lutzoni, F.M., Yonish, B.A., West, M.A., Black, M.N.D., Tester, P.A., 2007. Recognizing dinoflagellate species using ITS rDNA sequences. J. Phycol. 43, 344-355.

Mamán, L., Fernández, R., Jaén, D., Mata, A.J., Jiménez, C., Morales, J., 2003. Estudio de las proliferaciones del dinoflagelado Gymnodinium catenatum (Graham) en la costa de Andalucía (sur Península Ibérica). VIII Reunión Ibérica Sobre Fitoplancton tóxico Y Biotoxinas. Tenerife Actas del Congreso.

McMahon, T., Silke, J., 1996. West coast of Ireland; winter toxicity of unknown aetiology in mussels. Harmful Algae News 14, 2.

Morales, J., Mamán, L., Rivera, M.C., Morillo, M., Collado, J., Jaén, D., 2001. Distribución del género Pseudo-nitzschia en el litoral de Andalucía durante el año 2000. VII Reunión Ibérica Sobre Fitoplancton tóxico Y Biotoxinas. Alicante Actas del Congreso.

Percopo, I., Siano, R., Rossi, R., Soprano, V., Sarno, D., Zingone, A., 2013. A new potentially toxic Azadinium species (Dinophyceae) from the Mediterranean Sea A. dexteroporum sp. nov. J. Phycol. 49, 950-966.

Rambaut, A., 2001. Se-Al. Sequence Alignment Program v2.0a72. (Oxford).

Salas, R., Tillmann, U., John, U., Kilcoyne, J., Burson, A., Cantwell, C., Hess, P., Jauffrais, T., Silke, J., 2011. The role of Azadinium spinosum (Dinophyceae) in the production of Azaspiracid Shellfish Poisoning in mussels. Harmful Algae 10 $774-783$.

Small, A.C., 2002. European mussel cultivation along the Atlantic coast: production status, problems and perspectives. Hydrobiologia 484, 89-98.

Taleb, H., Vale, P., Amanhir, R., Benhadouch, A., Sagou, R., Chafik, A., 2006. First detection of azaspiracids in mussels in north west Africa. J. Shellifish Res. 25, 1067-1070.

Tillmann, U., Akselman, R., 2016. Revisiting the 1991 algal bloom in shelf waters off Argentina: Azadinium luciferelloides sp nov. (Amphidomataceae, Dinophyceae) as the causative species in a diverse community of other amphidomataceans. Phycol. Res. 64, 160-175.

Tillmann, U., Elbrächter, M., Krock, B., John, U., Cembella, A., 2009. Azadinium spinosum gen. et sp. nov. (Dinophyceae) identified as a primary producer of azaspiracid toxins. Eur. J. Phycol. 44, 63-79.
Tillmann, U., Salas, R., Gottschling, M., Krock, B., O’Driscoll, D., Elbrächter, M., 2012a. Amphidoma languida sp. nov. (Dinophyceae) reveals a close relationship between Amphidoma and Azadinium. Protist 163, 701-719.

Tillmann, U., Söhner, S., Nézan, E., Krock, B., 2012b. First record of Azadinium from the Shetland Islands including the description of $A$. polongum sp. nov. Harmful Algae 20, 142-155.

Tillmann, U., Gottschling, M., Nézan, E., Krock, B., Bilien, G., 2014a. Morphological and molecular characterization of three new Azadinium species (Amphidomataceae, Dinophyceae) from the Irminger Sea. Protist 165, 417-444.

Tillmann, U., Salas, R., Jauffrais, T., Hess, P., Silke, J., 2014b. AZA: the producing Organisms-Biology and trophic transfer. In: Botana, L.M. (Ed.), Seafood and Freshwater Toxins. CRC Press, Boca Raton, USA, pp. 773-798.

Tillmann, U., Gottschling, M., Nézan, E., Krock, B., 2015. First record of Azadinium dexteroporum and Amphidoma languida (Amphidomataceae, Dinophyceae) from the Irminger Sea off Iceland. Mar. Biodivers. Rec. 8, 1-11.

Tillmann, U., Borel, M., Barrera, F., Lara, R., Krock, B., Almandoz, G., Trefault, N., 2016 Azadinium poporum (Dinophyceae) from the South Atlantic off the Argentinean coast produce AZA-2. Harmful Algae 51, 40-55.

Torgersen, T., Bruun Bremmens, N., Rundberget, T., Aune, T., 2008. Structural confirmation and occurrence of azaspiracids in Scandinavian brown crabs (Cancer pagurus). Toxicon 51, 93-101.

Trainer, V.L., Moore, L., Bill, B.D., Adams, N.G., Harrington, N., Borchert, J., Da Silva, D. A.M., Eberhard, B.T.L., 2013. Diarrhetic shellfish toxins and other lipophilic toxins of human health concern in Washington State. Mar. Drugs 11, 1815-1835.

Turner, A.D., Goya, A.B., 2015. Occurrence and profiles of lipophilic toxins in shellfish harvested from Argentina. Toxicon 102, 32-42.

Twiner, M.J., El-Ladki, R., Kilcoyne, J., Doucette, G.J., 2012. Comparative effects of the marine algal toxin azaspiracid-1, $-2,1$ nd-3 on Jurkat T lymphocyte cells. Chem. Res. Toxicol. 25, 747-754.

Twiner, M., Hess, P., Doucette, G.J., 2014. Azaspiracids: toxicology, pharmacology, and risk assessment. In: Botana, L.M. (Ed.), Seafood and Freshwater Toxins. CRC Press, Boca Raton, USA, pp. 823-855.

Ueoka, R., Ito, A., Izumikawa, M., Maeda, S., Takagi, M., Shin-Ya, K., Yoshida, M., van Soest, R.W.M., Matsunaga, S., 2009. Isolation of azaspiracid-2 from a marine sponge Echinoclathria sp. as a potent cytotoxin. Toxicon 53, 680-684.

Vale, P., Bire, R., Hess, P., 2008. Confirmation by LC-MS/MS of azaspiracids in shellfish from the Portuguese north-west coast. Toxicon 51, 1449-1456.

Yao, J., Tan, Z., Zhou, D., Guo, M., Xing, L., Yang, S., 2010. Determination of azaspiracid-1 in shellfishes by liquid chromatography with tandem mass spectrometry. Chin. J. Chromatogr. 28, 363-367. 